\title{
Promising self-emulsifying drug delivery system loaded with lycopene from red guava (Psidium guajava L.): in vivo toxicity, biodistribution and cytotoxicity on DU-145 prostate cancer cells
}

\author{
Andreanne G. Vasconcelos ${ }^{1}$, Ana Luisa A. N. Barros ${ }^{1}$, Wanessa F. Cabral ${ }^{1}$, Daniel C. Moreira', \\ Ingrid Gracielle M. da Silva², Amandda É. Silva-Carvalho ${ }^{3}$, Miguel P. de Almeida ${ }^{4}$, Lucas F. F. Albuquerque, \\ Raimunda C. dos Santos ${ }^{5}$, Ana Karolinne S. Brito ${ }^{6}$, Felipe Saldanha-Araújo ${ }^{3}$, Daniel D. R. Arcanjo ${ }^{6}$, Maria \\ do Carmo C. Martins ${ }^{6}$, Tatiana K. dos S. Borges ${ }^{1}$, Sônia N. Báo ${ }^{2}$, Alexandra Plácido ${ }^{4}$, Peter Eaton ${ }^{4,7}$, \\ Selma A. S. Kuckelhaus ${ }^{1}$ and José Roberto S. A. Leite ${ }^{1 *}$ (D)
}

${ }^{*}$ Correspondence:

jrsaleite@gmail.com;

jrleite@pq.cnpq.br

${ }^{1}$ Núcleo de Pesquisa Em

Morfologia E Imunologia Aplicada, Área de Morfologia, Faculdade de Medicina, Universidade de Brasília, UnB, Campus Universitário Darcy Ribeiro, Asa Norte, Brasília, NuPMIADF 70910900, Brazil Full list of author information is available at the end of the article

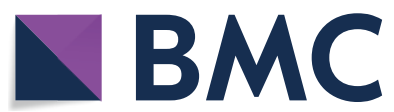

(c) The Author(s), 2021. Open Access This article is licensed under a Creative Commons Attribution 4.0 International License, which permits use, sharing, adaptation, distribution and reproduction in any medium or format, as long as you give appropriate credit to the original author(s) and the source, provide a link to the Creative Commons licence, and indicate if changes were made. The images or other third party material in this article are included in the article's Creative Commons licence, unless indicated otherwise in a credit line to the material. If material is not included in the article's Creative Commons licence and your intended use is not permitted by statutory regulation or exceeds the permitted use, you will need to obtain permission directly from the copyright holder. To view a copy of this licence, visit http:// creativecommons.org/licenses/by/4.0/. The Creative Commons Public Domain Dedication waiver (http://creativecommons.org/publi cdomain/zero/1.0/) applies to the data made available in this article, unless otherwise stated in a credit line to the data.
Results: NanoLPG exhibited physicochemical properties with a size around $200 \mathrm{~nm}$, negative zeta-potential, and spherical morphology. The size, polydispersity index, and zeta potential parameters suffered insignificant alterations during the 12 month storage at $5^{\circ} \mathrm{C}$, which were associated with lycopene stability at $5^{\circ} \mathrm{C}$ for 10 months. The nanoemulsion showed partial aggregation in cell culture medium at $37^{\circ} \mathrm{C}$ after $24 \mathrm{~h}$. NanoLPG at $0.10 \mathrm{mg} / \mathrm{mL}$ exhibited radical scavenging activity equivalent to $0.043 \pm 0.002 \mathrm{mg}$ Trolox $/ \mathrm{mL}$. The in vivo studies did not reveal any significant changes in clinical, behavioral, hematological, biochemical, and histopathological parameters in mice orally treated with nanoLPG at $10 \mathrm{mg} / \mathrm{kg}$ for 28 days. In addition, nanoLPG successfully delivered lycopene to the liver, kidney and prostate in mice, improved its cytotoxicity against DU-145 prostate cancer cells - probably by pathway independent on classical necrosis and apoptosis - and did not affect PBMC viability. 
Conclusions: Thus, nanoLPG stands as a promising and biosafe lycopene delivery system for further development of nanotechnology-based health products.

Keywords: Nanomedicine, Self-emulsifying, Guava fruit, Carotenoids, Antitumoral Graphical Abstract

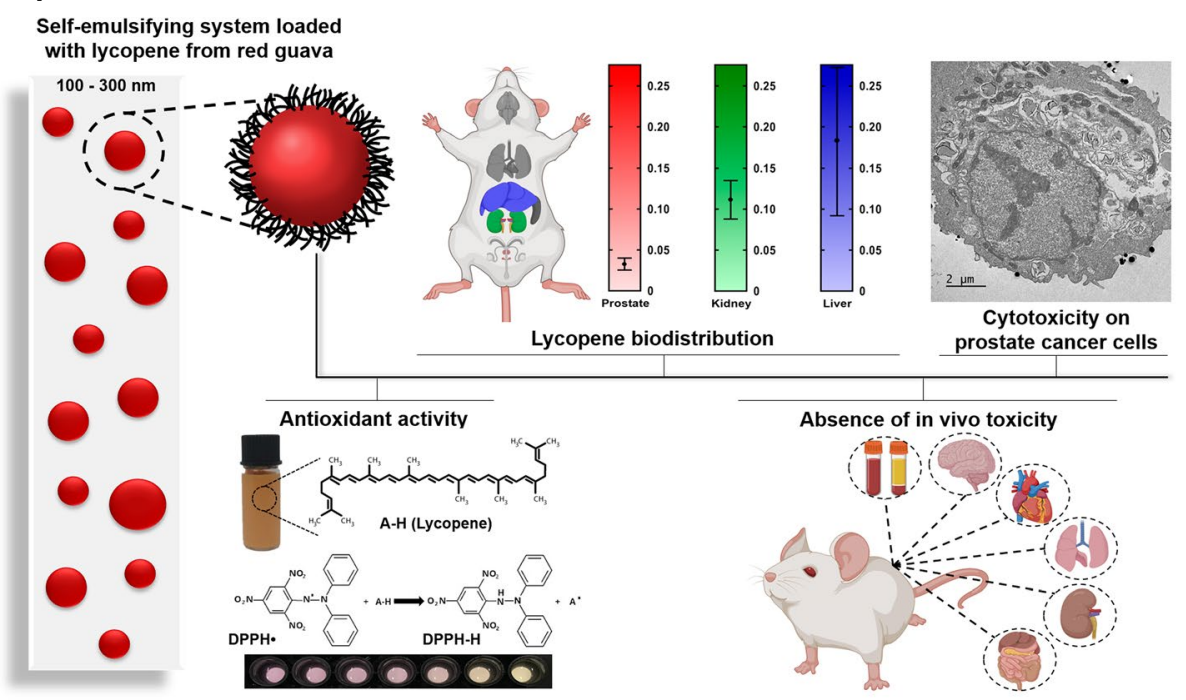

1- A SEDDS loading lycopene from red guava was efficiently produced;

2- NanoLPG showed satisfactory physico-chemical properties, antioxidant activity, lycopene biodistribution, biosafety and cytotoxicity on prostate cancer cells.

\section{Background}

Lycopene $\left(\mathrm{C}_{40} \mathrm{H}_{56}\right)$ is an aliphatic-chain carotenoid produced naturally by orangey-red fruits and vegetables, fungi, bacteria, and algae (Przybylska 2020). It is a well-known antioxidant that has been associated with protection against chemical and natural toxicants, cardiovascular disease, inflammation, neurodegenerative disease, diabetes, and many cancer types (Przybylska 2020; Ejike et al. 2018; Hedayati et al. 2019). As previously reported, lycopene-rich extracts can be successfully produced from the red guava (Psidium guajava Lineu), resulting in a high antioxidant activity $(2890 \pm 34 \mu \mathrm{M}$ Trolox/g by ABTS method) (Amorim et al. 2018). The intraperitoneal and oral administration of a lycopene-rich extract from red guava (LEG) and lycopene purified from red guava (LPG) inhibit acute inflammation caused by carrageenan in Swiss mice at 50 and $12.5 \mathrm{mg} / \mathrm{kg}$, respectively (Vasconcelos et al. 2017). Furthermore, LEG treatment significantly reduces the viability of human breast adenocarcinoma cell (MCF7) $\left(\mathrm{IC}_{50}=29.85\right.$ and $5.96 \mu \mathrm{g} / \mathrm{mL}$ at 24 and $72 \mathrm{~h}$, respectively), as well as decreases the levels of plasma triglycerides and lipid peroxidation biomarkers in hamsters (Santos et al. 2018; Silva Brito et al. 2019).

Despite its broad applications, lycopene can be isomerized or completely degraded when exposed to light, oxygen and temperature variation, losing its biological activity. Moreover, lycopene has poor oral bioavailability and water solubility, which are challenges for the development of commercial products containing carotenoids (Chernyshova et al. 2019; Srivastava and Srivastava 2015). In this context, nanobiotechnology 
has been an innovative alternative to improve the stability and biological activities of this compound. For example, lipid-core nanocapsules with a polysorbate 80 -coated poly- $\varepsilon$ caprolactone wall efficiently stabilize LEG for 7 months and improve its cytotoxic activity on breast cancer cells (Vasconcelos et al. 2020).

Among the main nanocarrier technologies available, self-emulsifying drug delivery systems (SEDDSs) have rapidly emerged in recent years as an attractive system to carry bioactive molecules with applications in food, cosmetics, chemical, and pharmaceutical industries. In addition to greatly improving the water solubility, physicochemical stability, and oral bioavailability of lipophilic compounds, SEDDSs are thermodynamically stable and easily produced (Betageri 2019; Singh et al. 2020). The production of SEDDSs relies on spontaneous emulsification, using oil, surfactants, and solvents, but it differs from conventional emulsification (Tran and Park 2021). The preparation of SEDDSs is carried out initially making a isotropic mixture of oil and surfactant at a gentle agitation followed by dilution within an aqueous phase, whereas in conventional emulsification all components are mixture at once to form an emulsion (Tran and Park 2021; Zhao et al. 2020).

In the present study, a promising formulation using a self-emulsifying drug delivery system loaded with lycopene purified from red guava, named nanoLPG, is presented. In addition, this work evaluated its physicochemical characteristics, antioxidant activity, in vivo toxicity, tissue distribution, and in vitro cytotoxicity on human prostate cancer cells to explore its potential application as an anti-cancer nanobiotechnology-based product.

\section{Materials and methods}

\section{Chemicals and reagents}

Analytical grade ethanol (Dinâmica), dichloromethane (Sharlab S. L.), acetone (Dinâmica), and Dimethylsulfoxide (DMSO, Dinâmica) and HPLC grade acetonitrile (Merck), methanol (Merck), N-hexane (Tedia), and ammonium acetate (J.T. Baker) were acquired. Chloroform, polysorbate 80 (Tween ${ }^{\circledR} 80$ ), sorbitane monostearate (Span $\left.{ }^{\circledR} 60\right)$, tomato lycopene standard (L9879, $\left.\geq 90 \%\right)$, Trolox (6-hydroxy-2,5,7,8-tetramethylchromane-2-carboxylic acid), DPPH (2,2-Diphenyl-1-picrylhydrazyl) and MTT (3-[4,5-dimethylthiazol-2-yl]-2,5-diphenyltetrazolium bromide) were purchased from Sigma-Aldrich Chemical Co (USA). Natural virgin coconut oil (Cocos nucifera L., Copra) was purchased from a local market in Brasília, DF, Brazil. Dulbecco's Modified Eagle's Medium (DMEM), heat-inactivated fetal bovine serum (FBS), 0.5\% trypsin-EDTA, and antibiotic solution were purchased from LGC Biotecnologia (Brazil). RPMI-1640 medium was purchased from Gibco BRL (USA).

\section{Production of lycopene purified from red guava}

Lycopene purified from red guava (LPG) was produced according to Amorim et al. (Amorim et al. 2018) and detailed in the patent number BR 102016030594-2 (Amorim et al. 2016). Red guavas (Psidium guajava L.) at a high degree of maturation were purchased from a local market in Parnaíba city, State of Piauí. The fruits (500 g) were submitted to dehydration with ethanol and extraction with dichloromethane under ultrasonic stirring. The extract was then filtered through quantitative filter paper and dried under 
reduced pressure (50 mbar) at room temperature in an R-215 rotary-evaporator (Buchi, Switzerland) under dim light. Subsequently, the extract was submitted to crystallization at $-20{ }^{\circ} \mathrm{C}$ and the purified lycopene was obtained by washing with ethanol and chloroform. After the extraction and purification, the isolated lycopene was stored at $-80^{\circ} \mathrm{C}$.

\section{Evaluation of the lycopene extract by UV-Vis spectrophotometry and High-Performance Liquid Chromatography (HPLC)}

UV-Vis analysis was performed to verify the absorption profile and to determine the content of lycopene equivalents in the extract using a Shimadzu UV-1280 spectrophotometer (Japan). LPG diluted in chloroform:ethanol (1:20) was scanned between 600 and $300 \mathrm{~nm}$ against a chloroform:ethanol blank solution in a quartz cuvette $(1 \mathrm{~mL})$. The quantification was carried out at $472 \mathrm{~nm}$, the maximum absorbance wavelength, using a calibration curve built with tomato lycopene standard solutions at concentrations from 1 to $10 \mu \mathrm{g} / \mathrm{mL}$.

For the HPLC analysis, the LPG was diluted in chloroform:ethanol (1:20), filtered through a $0.45 \mu \mathrm{m}$ PTFE syringe filter and injected $(20 \mu \mathrm{L})$ in a high-performance liquid chromatography system (Shimadzu, Japan) equipped with a RPAQUEOUS Develosil C30 $(4.6 \times 150 \mathrm{~mm}, 5 \mu \mathrm{m})$ column and a photodiode-array detector (PDA, SPD-M20A). The mobile phase was composed of acetonitrile, methanol, hexane, dichloromethane, and ammonium acetate (55:22:11.5:11.5:0.02, v:v:v:v:w) at a flow rate of $1 \mathrm{~mL} / \mathrm{min}$ from 0 to $20 \mathrm{~min}$. Detection was performed over the range of 800 $200 \mathrm{~nm}$ at $1.2 \mathrm{~nm} / \mathrm{s}$, with live monitoring at $472 \mathrm{~nm}$.

\section{Synthesis and characterization of nanoemulsion}

Production of self-emulsifying drug delivery system containing lycopene purified from red guava

Self-emulsifying drug delivery systems containing lycopene purified from red guava (nanoLPG) were produced according to Yen et al. (1853), with modifications. LPG, sorbitan monostearate, and coconut oil (1:10:0.06, w:w:v) were mixed in ethanol:acetone $(1: 8, \mathrm{v}: \mathrm{v})$ under magnetic stirring for $10 \mathrm{~min}$ at $40{ }^{\circ} \mathrm{C}$. Then, the mixture was poured into distilled water $(\mathrm{pH} 7.0)$ containing polysorbate $80(0.45 \mathrm{~g})$ under the same conditions of stir and temperature, following the organic:aqueous phase proportion of 1:2.5 (v:v). The formulation was concentrated under reduced pressure (30 mbar) at $37{ }^{\circ} \mathrm{C}$ in an R-215 rotary-evaporator (Buchi, Switzerland) until a final volume of $20 \mathrm{~mL}$, eliminating the organic solvents. The resulting nanoLPG formulation was stored in tightly closed plastic bottles in a refrigerator $\left(5-8^{\circ} \mathrm{C}\right)$. The preparation of the SEDDS was carried out under dim light.

\section{Dynamics Light Scattering (DLS) and zeta potential}

Mean particle size (z-average) and polydispersity index (PDI) were measured by DLS using a Zetasizer Nano-ZS90 (Malvern, UK). The samples were freshly diluted in ultrapure water $(1: 400,1 \mathrm{~mL})$ and analyzed in triplicate, at an angle of $90^{\circ}$ with an equilibration time of $60 \mathrm{~s}$ at $25^{\circ} \mathrm{C}$ before measurement. The zeta potential was determined under the same conditions. The analyses were carried out immediately after the synthesis and then monthly, for 12 months. 


\section{Nanoparticle tracking analysis (NTA)}

NanoLPG was diluted 50,000 times in ultrapure water and the hydrodynamic diameter and concentration of particles suspended in the medium were measured using a Malvern Panaltyical NanoSight NS300 instrument, equipped with a $642 \mathrm{~nm}$ laser module (Malvern, UK). Data collection and analysis were performed using NTA 3.2 software. Five videos of 1-min length each were captured, under the following parameters: flow cell at a $2 \mu \mathrm{L} / \mathrm{min}$ rate, temperature of $25^{\circ} \mathrm{C}$, water viscosity value of $0.9 \mathrm{cP}$, and detection threshold of 4 . Each video was analyzed independently and the results were automatically merged into a particle size distribution chart.

\section{Lycopene content}

Lycopene content in the nanoLPG was determined spectrophotometrically. The nanoemulsion $(50 \mu \mathrm{L})$ was diluted in $950 \mu \mathrm{L}$ of chloroform:saturated sodium chloride solution $(1: 1, \mathrm{v}: \mathrm{v})$. The sample was mixed for $1 \mathrm{~min}$ and then centrifuged at $1000 \mathrm{rpm}$ for $5 \mathrm{~min}$. The chloroform phase (lower phase) was scanned from 600 to $300 \mathrm{~nm}$ in a quartz cuvette $(1 \mathrm{~mL})$, with quantification at $472 \mathrm{~nm}$ using a Shimadzu UV-1280 spectrophotometer (Japan). Free LPG was also analyzed to evaluate the stability under the same storage conditions as the nanoLPG as described in "Evaluation of the lycopene extract by UV-Vis spectrophotometry and High-Performance Liquid Chromatography (HPLC)” section. Readings of nanoemulsion's constituents without LPG were carried out to exclude any interference of the formulation on lycopene light absorbance.

\section{Transmission Electron Microscopy (TEM)}

The ultrastructure of nanoLPG was evaluated by TEM using a Jeol JEM-1011 microscope (Japan). The sample was diluted 1000 times in ultrapure water and deposited on formvar-coated grids. After that, the sample was stained with uranyl acetate, washed, air-dried, and examined at $80 \mathrm{keV}$.

\section{Fourier-Transform Infrared Spectroscopy (FTIR)}

FTIR spectra were measured in the attenuated total reflectance (ATR) mode using a Perkin-Elmer Spectrum BX FTIR spectrometer fitted with a diamond single crystal ATR accessory. Measurements were made between 500 and 3000 wavenumbers with a resolution of 2 wavenumbers.

\section{Colloidal stability of nanoLPG in biological medium}

The colloidal stability of nanoLPG in cell culture medium was investigated following Friedrich et al. (2015). Nanoemulsion was diluted in DMEM supplemented with 10\% $(\mathrm{v} / \mathrm{v})$ heat-inactivated fetal bovine serum and $1 \%(\mathrm{v} / \mathrm{v})$ antibiotic solution $(5000 \mathrm{U} / \mathrm{mL}$ penicillin and 5,000 U/mL streptomycin) at concentrations of 3.125, 25 and $200 \mu \mathrm{g} / \mathrm{mL}$. These concentrations were based on lycopene content in nanoLPG and subsequent cytotoxic assay. Mean particle size (z-average) and polydispersity index (PDI) were measured by DLS using a Zetasizer Nano-ZS90 (Malvern, UK) immediately and upon $24 \mathrm{~h}$ of incubation at $37^{\circ} \mathrm{C}$ and $5 \% \mathrm{CO}_{2}$ in a humidified atmosphere. 


\section{Antioxidant activity}

The antioxidant activity of nanoLPG was assessed using the DPPH radical scavenging assay. A stock solution of $100 \mu \mathrm{M}$ DPPH was prepared in HPLC-grade ethanol and kept at $-20{ }^{\circ} \mathrm{C}$ for no longer than a week. Just before the experiment, the stock DPPH solution was diluted to achieve an absorbance of 0.700 at $517 \mathrm{~nm}$ to produce the DPPH working solution. The nanoemulsion was diluted to $0.10 \mathrm{mg} / \mathrm{mL}$ in phosphate-buffered saline (PBS) and $25 \mu \mathrm{L}$ was mixed with $225 \mu \mathrm{L}$ of DPPH working solution in microtubes. Tubes were incubated in the dark at room temperature for $30 \mathrm{~min}$. After incubation, samples were centrifuged at $5000 \times g$ for $5 \mathrm{~min}$ to remove any insoluble material. Then, $200 \mu \mathrm{L}$ of the supernatant were transferred to 96-well black flat-bottom microplates (\#3605, Corning, USA) and read at $517 \mathrm{~nm}$ in a microplate reader (Spectramax ${ }^{\circledR}$ Plus 384, Molecular Devices, USA). To account for the possible interference of nanoparticles at $517 \mathrm{~nm}$ control assays using nanoemulsion and ethanol (without DPPH) were run in parallel. The ability of nanoLPG to scavenge DPPH radicals was compared to that of several dilutions of Trolox in PBS in a standard curve ranging from 12.5 to $200 \mu \mathrm{M}$. The assay was run in triplicate and results are expressed as $\mu \mathrm{M}$ of Trolox equivalents/g of nanoLPG.

\section{In vivo studies}

\section{Animals and ethics}

The Animal Ethics Committee of the Institute of Biology of the University of Brasília, UnB approved all experiments with animals reported in this study under the protocol number 09/2019. The procedures were performed following the National Council for Animal Experimentation Control (CONCEA, Brazil) guidelines and current national legislation, Brazilian Laws 11,794/2008 and 9,605/1998.

Male Swiss mice ( $25 \pm 5 \mathrm{~g}, 8-12$ weeks) obtained from the bioterium of the Medicinal Plants Research Center (NPPM) of the Federal University of Piauí (UFPI, Brazil) were used for the acute toxicity evaluation of LPG. Male Swiss mice ( $30 \pm 5 \mathrm{~g}, 6-8$ weeks) were maintained in the bioterium of the Faculty of Medicine of the University of Brasília (UnB, Brazil) for the repeated-dose toxicity and biodistribution studies of nanoLPG. The animals were maintained at $22 \pm 2{ }^{\circ} \mathrm{C}$ under a $12 / 12$ light/dark cycle with free access to water and food.

\section{Acute oral toxicity of $L P G$}

Mice were randomly distributed into two groups $(N=5$, each) and treated with water (control group) or LPG at the single dose of $2000 \mathrm{mg} / \mathrm{kg}$ (test group) by oral route. Animals were observed over $8 \mathrm{~h}$ on the first day and, then, daily for 14 days for signs of acute toxicity, according to the guideline 420: Acute Oral Toxicity-Fixed Dose Procedure of the Organization for Economic Cooperation and Development (OECD 2002a).

\section{Repeated-dose oral toxicity of the nanoLPG}

The in vivo toxic effect of nanoLPG was evaluated according to the guideline 407: Repeated Dose 28-day Oral Toxicity Study in Rodents of the Organization for Economic Cooperation and Development (OECD 2008). The animals were randomly distributed 
into two groups $(N=9$, each) and treated with water (control group) or nanoLPG at $10 \mathrm{mg} / \mathrm{kg}$ (test group) daily by oral route for 28 days. The animals were euthanized 1 day after the last dose, with ketamine and xylazine administered intraperitoneally, as stipulated by the National Council for Animal Experimentation Control (CONCEA, Brazil) Euthanasia Practice Guideline.

Clinical and behavioral analysis Clinical and behavioral parameters were evaluated in accordance with the Guidance Document on the Recognition, Assessment and Use of Clinical Signs as Human Endpoints for Experimental Animals Used in Safety Evaluation from the OECD (OECD 2002b). Scores were attributed to measure the degree of change of the parameter, where zero (0) was without effect and three (3) was a severe effect. Body weight gain and food and water consumption were also evaluated daily for 4 days and then every 3 days for 28 days. After euthanasia, the organs were removed, their clinical aspect was examined and the weights were measured.

Biochemical and hematological parameters Blood samples were collected by heart puncture in tubes without and with EDTA for biochemical and hematological analysis, respectively. The levels of biochemical markers, glucose, urea, creatinine, cholesterol, triglycerides, alanine aminotransferase (ALT), aspartate aminotransferase (AST), and alkaline phosphatase (ALP), were measured using a semi-automated biochemical analyzer (Bio-200, BIOPLUS, Brazil) and LABTEST ${ }^{\circledR}$ reagents (Brazil) according to the manufacturer instructions.

The hemogram was assayed using an automated hematological analyzer (SDH-3 VET, LABTEST ${ }^{\circledR}$, Brazil). The hemoglobin content and total plasmatic proteins were measured in a semi-automated biochemical analyzer (Bio-200, BIOPLUS, Brazil). The morphological analysis of leukocytes and erythrocytes was performed using blood smear samples stained by the panoptic method (NEWPROV, Brazil) under an optical microscope.

Histopathological analysis Animals were randomly distributed into two groups $(N=5$, each) and treated with water (control group) or nanoLPG at $10 \mathrm{mg} / \mathrm{kg}$ (test group) at repeated-dose by oral route over 28 days. Brain, heart, aorta, lung, liver, spleen, stomach, esophagus, small intestine, large intestine, pancreas, and kidney were fixed in $10 \%$ neutral buffered formalin for $24 \mathrm{~h}$. Tissue specimens were dehydrated in increasing concentrations of ethanol, diaphanized in xylene, and embedded in histological paraffin. The samples were sectioned at 4-6 $\mu \mathrm{m}$ intervals and stained with hematoxylin and eosin (H\&E). Histological sections were examined using ScanScope Aperio (Leica Biosystem Inc, USA) equipped with image processing and capture system ScanScope Cansole v10.2.0.2352 at $400 \times$ magnification. The histopathological analyses were performed by one observer in all sections to evaluate the architecture of the tissue and to perform semi-quantitative analysis. The histopathological changes were ranked from normal to severe lesions.

Bioavailability Animals were randomly distributed into two groups $(N=9$, each) and treated with water (control group) or nanoLPG at $10 \mathrm{mg} / \mathrm{kg}$ (test group) at repeateddose by oral route over 28 days. Brain, heart, lung, liver, spleen, kidney, and pros- 
tate were frozen in liquid nitrogen and preserved at $-80^{\circ} \mathrm{C}$. Organ specimens $(100-$ $300 \mathrm{mg}$ ) were homogenized in a solution of ethanol, water, butylhydroxytoluene, and potassium hydroxide (54.99:44.98:0.02:0.01) at 1:5 (w:v) under ultrasonic stirring for 15 min a $50{ }^{\circ} \mathrm{C}$ followed by water/ice bath. Lycopene extraction from the homogenate was carried out with $2 \mathrm{~mL}$ dichloromethane:hexane (1:5, v:v). Samples were centrifuged at $4000 \mathrm{rpm}$ for $10 \mathrm{~min}$ at $10{ }^{\circ} \mathrm{C}$ and the supernatant was collected, filtrated, and dried using a LabConco CentriVap Concentrator (USA). The extraction process was repeated three times.

The concentration of lycopene in the organs was determined by HPLC. Samples were injected $(70 \mu \mathrm{L})$ in a high-performance liquid chromatography system (Shimadzu, Japan) equipped with a RPAQUEOUS Develosil C30 $(4.6 \times 150 \mathrm{~mm}, 5 \mu \mathrm{m})$ column and a photodiode-array detector (PDA, SPD-M20A). The mobile phase was composed of acetonitrile, methanol, hexane, dichloromethane, and ammonium acetate (55:22:11.5:11.5:0.02, $\mathrm{v}: \mathrm{v}: \mathrm{v}: \mathrm{v}: \mathrm{w})$ at a flow rate of $1 \mathrm{~mL} / \mathrm{min}$ from 0 to $20 \mathrm{~min}$. Detection was performed over the range of $800-200 \mathrm{~nm}$ at $1.2 \mathrm{~nm} / \mathrm{s}$, with live monitoring at $472 \mathrm{~nm}$. A calibration curve built with several dilutions $(0-20 \mu \mathrm{g} / \mathrm{mL})$ of tomato lycopene standard solution was used to quantify lycopene content in the samples.

\section{In vitro cytotoxicity}

\section{Viability of prostate cancer cells}

Human prostate carcinoma cell line (DU-145) was acquired from Rio de Janeiro Cell Bank (BCRJ) and cultured in DMEM supplemented with 10\% (v/v) FBS and 1\% (v/v) antibiotic solution (5000 U/mL penicillin and streptomycin) at $37{ }^{\circ} \mathrm{C}$ and $5 \% \mathrm{CO}_{2}$ in a humidified atmosphere.

Cell viability was assessed using the MTT method. Briefly, cells were seeded in 96-well culture plates at $3 \times 10^{3} \mathrm{cell} /$ well and maintained at $37{ }^{\circ} \mathrm{C}$ for $24 \mathrm{~h}$. Then, cells were treated with nanoLPG at concentrations ranging from 200 to $3.125 \mu \mathrm{g} / \mathrm{mL}$. DMEM, $20 \%(\mathrm{v} / \mathrm{v})$ DMSO and free LPG diluted in $0.5 \%(\mathrm{v} / \mathrm{v})$ DMSO (200 to $6.25 \mu \mathrm{g} / \mathrm{mL}$ ) were used as control treatments. The cells were incubated for $6,12,24,48$, and $72 \mathrm{~h}$ with each treatment. After the exposure time, the medium was removed and $100 \mu \mathrm{L}$ of MTT solution diluted in DMEM $(0.75 \mathrm{mg} / \mathrm{mL})$ was added in each well and incubated at $37{ }^{\circ} \mathrm{C}$ for $2 \mathrm{~h}$. DMSO $(100 \mu \mathrm{L})$ was then added to dissolve the formazan salts produced by living cells. The absorbance was measured at $595 \mathrm{~nm}$ using a SpectraMax ${ }^{\circledR}$ Plus 384 microplate reader (Molecular Devices, USA). Data were representative of the triplicate of two independent experiments.

\section{Cell membrane integrity assay}

Cell membrane integrity of DU-145 cells was evaluated using the trypan blue staining method. Cells were treated with nanoLPG and free LPG at 200 and $6.89 \mu \mathrm{g} / \mathrm{mL}$ in triplicate and incubated for $24 \mathrm{~h}$. DMEM and 20\% DMSO were used as control treatments. After the exposure time, cells were detached using trypsin, centrifuged at $2500 \mathrm{rpm}$ for $5 \mathrm{~min}$ at $4{ }^{\circ} \mathrm{C}$, and washed with PBS three times. The cell suspensions $(50 \mu \mathrm{L})$ were stained with $0.4 \%$ trypan blue solution in PBS $(1: 1, \mathrm{v}: \mathrm{v})$ and cells in $10 \mu \mathrm{L}$ were counted 
using a Neubauer chamber. Cell membrane integrity was classified as disrupted or undamaged according to their appearance under an optical microscope. Representative fields of control and treated DU-145 cells were captured at $100 \times$ magnification using a Nikon Eclipse Ts2 microscope (Japan) with Nis Elements L Imaging Software (version 1.02.00).

\section{Flow cytometry and fluorescence microscopy analyses}

To evaluate the cell death mechanism triggered by nanoLPG in cancer cells, the Annexin-V FITC/PI staining assay was used to distinguish apoptotic from necrotic cells. DU-145 cells were seeded into 24 -well culture plates at a density $1.5 \times 10^{5}$ cell/ well and maintained at $37{ }^{\circ} \mathrm{C}$ for $24 \mathrm{~h}$. After treatment with nanoLPG or LPG (6.89 and $200 \mu \mathrm{g} / \mathrm{mL}$ ) and incubation for $24 \mathrm{~h}$ at $37^{\circ} \mathrm{C}$, cells were detached with trypsin, centrifuged at $2500 \mathrm{rpm}$ for $5 \mathrm{~min}$ at $4{ }^{\circ} \mathrm{C}$, and washed with PBS three times. The cells were resuspended in $100 \mu \mathrm{L}$ of binding buffer (BD Pharmingen ${ }^{\mathrm{TM}}$ ), labeled with $5 \mu \mathrm{L}$ of Annexin-V FITC and $10 \mu \mathrm{L}$ of propidium iodide (PI) (BD Pharmingen ${ }^{\mathrm{TM}}$ ), and incubated at room temperature for $15 \mathrm{~min}$ in the dark. Then, $100 \mu \mathrm{L}$ of binding buffer were added and the cell suspension was analyzed by flow cytometry (LSR II Fortessa ${ }^{\mathrm{TM}}$, BD, USA) with a total of 20,000 events per sample. DMEM and 20\% DMSO were used as control treatments. The assay was carried out in triplicate. Photomicrographs from phase contrast and fluorescence microscopy representative of the control and treated DU-145 cells were obtained using a Nikon Eclipse Ts2 microscope (Japan) with Nis Elements L Imaging Software (version 1.02.00) at $200 \times$ magnification.

\section{Ultrastructural analysis of cancer cells}

DU-145 cells at a density $1 \times 10^{6}$ cell/well were treated with DMEM (control), free LPG or nanoLPG (6.89 and $200 \mu \mathrm{g} / \mathrm{mL})$ and incubated at $37^{\circ} \mathrm{C}$ for $24 \mathrm{~h}$. Cells were detached with trypsin, centrifuged at $2500 \mathrm{rpm}$ for $5 \mathrm{~min}$ at $4{ }^{\circ} \mathrm{C}$, washed with PBS three times and fixed in Karnovsky's fixative solution. Samples were washed, fixed with osmium tetroxide (1\%), dehydrated using acetone (50-100\%), and embedded in Spurr resin. Cells stained with $0.5 \%$ uranyl acetate were examined by TEM using a Jeol JEM-1011 microscope (Japan).

\section{Viability of human peripheral blood mononuclear cells}

Human peripheral blood mononuclear cells (PBMC) were isolated using a FicollPaque density gradient (Amersham Biosciences) from peripheral blood samples collected from healthy donors in tubes containing EDTA as anticoagulant. Cells were cultured in RPMI supplemented with $10 \%(\mathrm{v} / \mathrm{v}) \mathrm{FBS}, 100 \mu \mathrm{g} / \mathrm{mL}$ penicillin and streptomycin and $2 \mathrm{mM}$ L-glutamine at $37{ }^{\circ} \mathrm{C}$ and $5 \% \mathrm{CO}_{2}$ in a humidified atmosphere. Cell viability assay was assessed using the MTT method with a cell density of $2 \times 10^{5}$ cell/well. The cells were treated with nanoLPG at concentrations ranging from 25 to $0.75 \mu \mathrm{g} / \mathrm{mL}$ or free LPG diluted in $0.5 \%$ (v/v) DMSO (25 to $0.75 \mu \mathrm{g} / \mathrm{mL}$ ) and incubated for 6, 12 and $24 \mathrm{~h}$. After the exposure time, the cells were treated with MTT solution $(5 \mathrm{mg} / \mathrm{mL})$ for $4 \mathrm{~h}$ at $37^{\circ} \mathrm{C}$, centrifugated at $400 \times g$ for $10 \mathrm{~min}$. Then, the culture medium was removed and DMSO $(100 \mu \mathrm{L})$ was added to dissolve the formazan 
salt. The absorbance was measured at $595 \mathrm{~nm}$ using a SpectraMax ${ }^{\circledR}$ Plus 384 microplate reader (Molecular Devices, USA).

\section{Statistical analysis}

The statistical analyses were performed using GraphPad Prism version 8.4.3 (GraphPad Software, USA). Kruskal-Wallis test followed by Dunn's multiple comparison test was used to verify statistical differences in the physicochemical parameters of the nanoemulsion over time. Unpaired $t$ test was used to analyze statistical differences in the colloidal stability and in vivo toxicity data. For cell experiments, data normality was tested using the Kolmogorov-Smirnov test and one-way analysis of variance (ANOVA) followed by Bonferroni's multiple comparison analyses were used to evaluate statistical differences between groups. Two-way ANOVA followed by Bonferroni's multiple comparison analyses were employed to compare means among the exposure times in the cytotoxicity assay. For all statistical analyses, $p$ values below 0.05 were considered to indicate statistically significant differences.

\section{Results and discussion}

\section{Characterization of LPG and nanoLPG}

LPG presented an absorption profile very similar to that of tomato lycopene analytical reference, exhibiting three maximum absorption bands $\left(\lambda_{\max }\right)$ at 503, 472 and $447 \mathrm{~nm}$ (Fig. 1a). The absorption spectrum of LPG was also similar to that reported by Amorim et al. (Amorim et al. 2018), which had $\lambda_{\max }$ values of 505, 473, and $448 \mathrm{~nm}$ corresponding to $5-Z$ lycopene. The quantification of lycopene revealed that the extraction method resulted in a yield of $97.70 \%$ of lycopene/dry extract weight and $82.18 \mathrm{mg}$ of lycopene $/ 100 \mathrm{~g}$ of fruit. The yield is comparable to that previous described using the same extraction methodology (61.66 $\pm 0.73 \mathrm{mg}$ of $5-Z$ lycopene/100 g of guava) (Amorim et al. 2018). The HPLC elution profile of LPG monitored at $472 \mathrm{~nm}$ showed a single major peak with a retention time (RT) of 9.49 min (Fig. 1b). This peak was identified as lycopene by comparison with the RT and DAD spectrum recorded for the tomato lycopene standard (9.53 $\mathrm{min})$.

A self-emulsifying drug delivery system containing lycopene purified from red guava (nanoLPG) was produced with previously used surfactants (Vasconcelos et al.
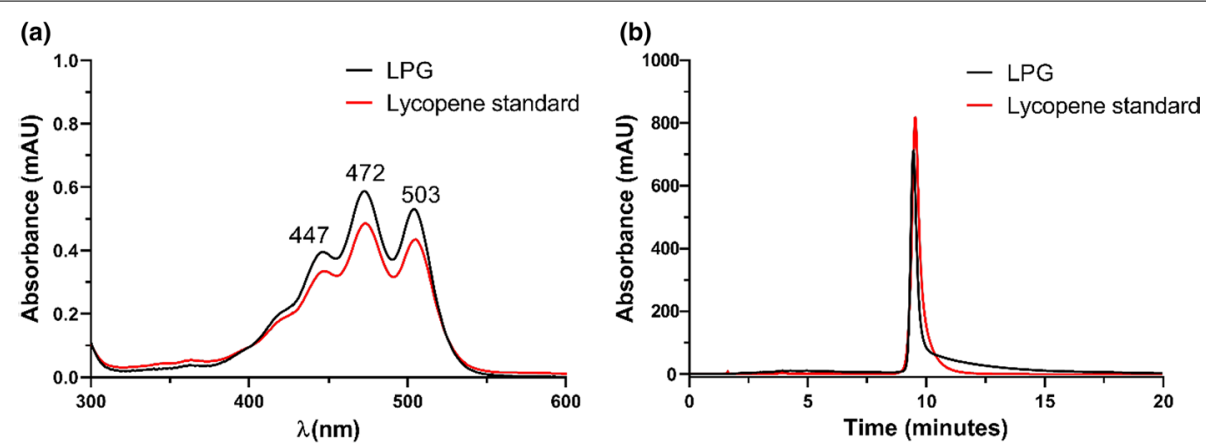

Fig. 1 UV-Vis spectrum from 600 to $300 \mathrm{~nm}$ (a) and chromatogram by PDA-HPLC (b) of the LPG and tomato lycopene analytical standard at the concentration of $50 \mu \mathrm{g} / \mathrm{mL}$ 
(a)

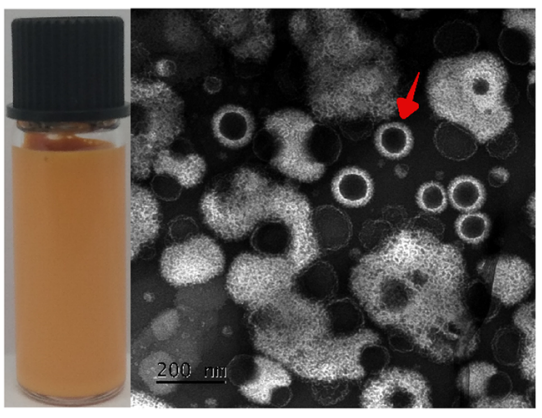

(b)

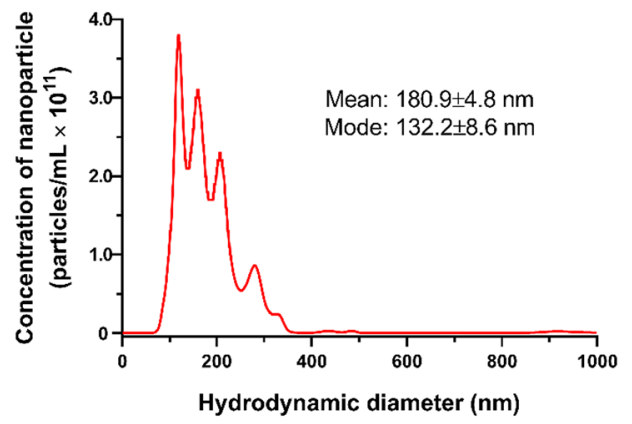

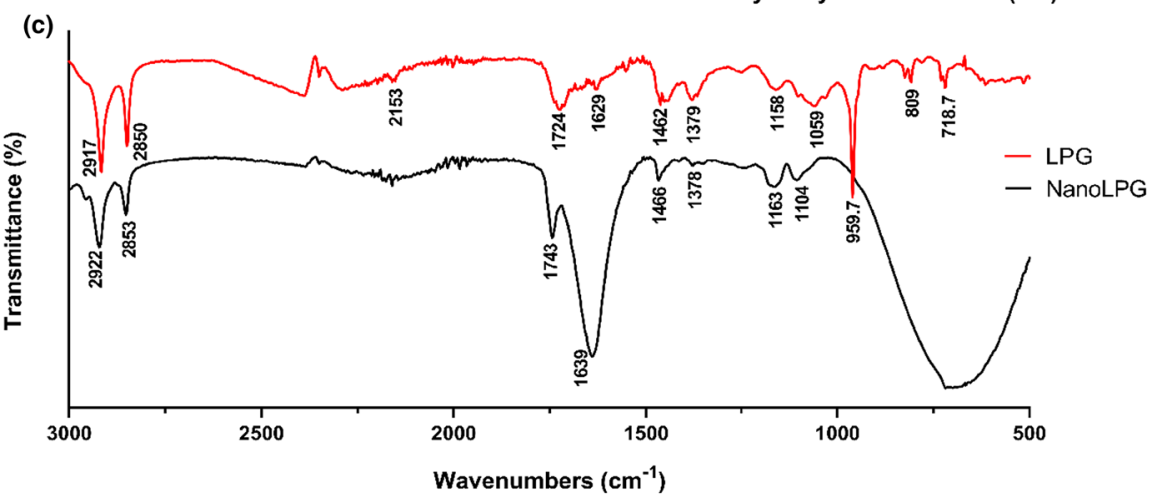

(d)

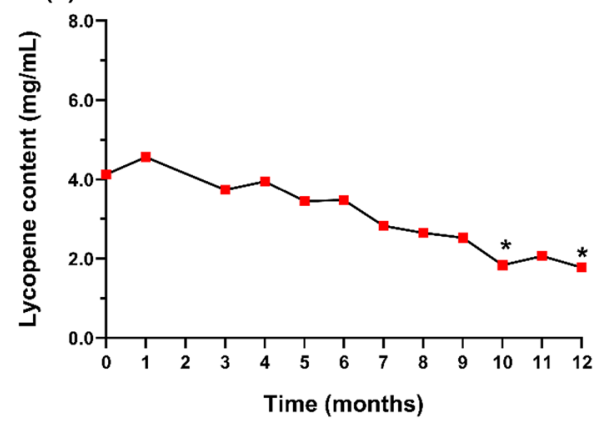

(e)

- LPG from nanoLPG (month 0)

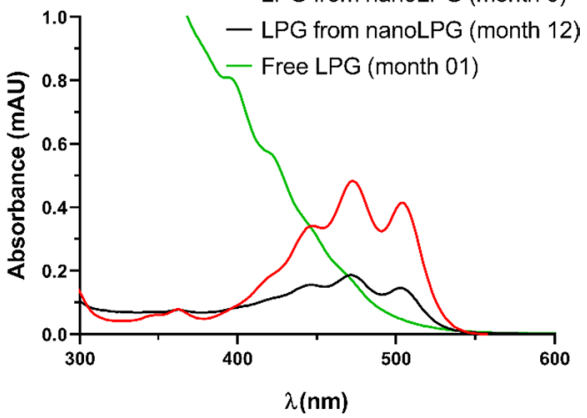

Fig. 2 Hydrodynamic diameter distribution from NTA measurements of nanoLPG (a). Photography of the nanoemulsion and photomicrography of nanoLPG (arrow) by Transmission Electron Microscopy (b). ATR-FTIR spectrum of LPG and nanoLPG (c). Lycopene content in nanoLPG over period of 12 months at $4{ }^{\circ} \mathrm{C}(\mathbf{d})$ and UV-Vis spectrum of LPG extracted from nanoemulsion and free LPG under the same storage conditions (e). Mean and mode in the NTA data were expressed as mean \pm SEM. ${ }^{*} p<0.05$ vs month 0

Table 1 Characterization of the nanoLPG

\begin{tabular}{llr}
\hline Parameter & Month & nanoLPG \\
\hline Size $(\mathrm{nm})^{\mathrm{a}}$ & 0 & $239.90 \pm 8.67$ \\
& 12 & $248.00 \pm 0.80$ \\
PDI $^{\mathrm{a}}$ & 0 & $0.22 \pm 0.03$ \\
& 12 & $0.21 \pm 0.02$ \\
Zeta potential $(\mathrm{mV})$ & 0 & $-28.30 \pm 0.52$ \\
& 12 & $-33.00 \pm 0.17$ \\
Lycopene content $(\mathrm{mg} / \mathrm{mL})$ & 0 & $4.13 \pm 0.02$ \\
& 12 & $1.78 \pm 0.01^{*}$ \\
\hline
\end{tabular}

a Data obtained by Dynamic Light Scattering (DLS)

Data were expressed as mean \pm SD. ${ }^{*} p<0.05$ vs month 0 
2020; Santos et al. 2015) classified as safe by Agência Nacional de Vigilância Sanitária (ANVISA, Brazil) and Food and Drug Administration (FDA, USA). NanoLPG formulation had a turbid, milky liquid, and homogeneous aspect (Fig. 2a). DLS analysis results indicated that nanoLPG was composed of polydisperse nanoparticles with an average diameter of approximately $200 \mathrm{~nm}$ (Table 1). NTA data (Fig. 2b) revealed a hydrodynamic diameter range from 100 to $300 \mathrm{~nm}$, with an average diameter of $180 \mathrm{~nm}$, corroborating DLS data. Nanoparticle concentration per milliliter was $3.74 \times 10^{11}$. Nanoparticle size is an important parameter for biological applications, since it can determine the stability of the delivery system by affecting sedimentation or aggregation rates, as well as cellular internalization and toxicity (Baranowska-Wójcik et al. 2020; Wang et al. 2020). In this study, nanoparticle size agreed with that reported in previous works on lycopene nanoparticles $(211.30 \pm 2.5$ and $250 \pm 8.21 \mathrm{~nm}$ ) (Vasconcelos et al. 2020; Wanyi et al. 2020). Although PDI and NTA data indicated polydispersity, nanoparticle size distribution was adequately uniform. For Silva et al. (Silva et al. 2020), PDI values from 0.1 to 0.5 express a sufficiently homogeneous size distribution. Indeed, wider size distribution ranges are associated with PDI values higher than 0.5 (González-Reza et al. 2018).

The zeta potential represents the charge on the surface of nanoparticles, indicating their cationic, anionic, or neutral character (Smith et al. 2017). The zeta potential of nanoLPG was negative (Table 1), contributing to the electrostatic repulsion, which prevents their aggregation and confers physical stability to the nanosystem. The negative value can be due to hydroxyl groups of tween 80 (Xiong et al. 2012; Zardini et al. 2018).

Taken together, size, polydispersity index, and zeta potential all indicate that nanoLPG was physicochemically stable up to 12 months, suffering insignificant alterations during the storage period (Table 1). In addition, TEM morphological analysis of nanoLPG showed nanoparticles with spherical shape and smooth topology (red arrow, Fig. 2a). The spherical shape is the most common morphology reported in scientific literature and is usually associated with a high potential for the preservation of encapsulated molecules. The preservation can be due to a small specific surface area and minimum contact with the aqueous environment (Zardini et al. 2018). Furthermore, spherical nanoparticles are more cytotoxic than those with other shapes when tested against HeLa cancer cells, probably because very small size and high aggregation of non-spherical nanoparticles (Woźniak et al. 2017).

The results from the ATR-FTIR analysis of LPG and nanoLPG are shown in Fig. 2c. In the FTIR spectrum of LPG, the peak at $959.7 \mathrm{~cm}^{-1}$ can be attributed to trans conjugated $\mathrm{C}-\mathrm{H}$ out-of-plane bending and the bands between 1379 and $1462 \mathrm{~cm}^{-1}$ are typical of $\mathrm{C}=\mathrm{C}$ lycopene stretching. In general, the vibrational frequencies of LPG were similar to those previously found for the lycopene-rich extract from red guava (LEG) (Santos et al. 2018). The absence of the sharp peak at $959.7 \mathrm{~cm}^{-1}$ could be related to the encapsulation of the LPG as suggested by Li et al. (2018), who also noted the disappearance of a peak at the same wavenumber upon nanoencapsulation (in a different system). However, it is not possible to rule out that this peak is obscured by the strong and broad $\mathrm{OH}$ band at $750 \mathrm{~cm}^{-1}$ from the water in the nanoLPG system.

Concerning the effect of storage on the amount of lycopene loaded in nanoLPG, lycopene content tended to decrease over time, but it was only at 10 months of storage (at $5-8{ }^{\circ} \mathrm{C}$ ) that lycopene loss was statically significant (Fig. 2d). Nevertheless, the UV-Vis 
profile of lycopene extracted from nanoemulsion after 12 months was still characteristic of this molecule, with the three bands of maximum absorption at 503, 471, and $447 \mathrm{~nm}$ (Fig. 1e). In contrast, the lycopene in free LPG stored under the same conditions was totally degraded in the first month (Fig. 2e). Lycopene degradation was characterized by a significant loss of absorbance around $503 \mathrm{~nm}$, absence of distinction between the three peaks, and a progressive increase in the absorbance in the region below $447 \mathrm{~nm}$, similar to previous descriptions of lycopene degradation (Vasconcelos et al. 2020; Tan and Soderstrom 1989). Temperature is one of the main factors that affect lycopene stability. High temperatures induce isomerization, followed by autooxidation of unsaturated bonds, which hinders further biological applications (Srivastava and Srivastava 2015; Aliyu et al. 2020). Our findings indicate that the nanoemulsion preserves lycopene integrity for months under refrigeration, allowing their biotechnological application.

The colloidal stability assay indicated that the incubation of nanoLPG diluted in DMEM at 3.125 and $25 \mu \mathrm{g} / \mathrm{mL}$ resulted in aggregation as evidenced by the increase in average particle size after $24 \mathrm{~h}$ at $37^{\circ} \mathrm{C}$ (Table 2). The change in PDI at $3.125 \mu \mathrm{g} / \mathrm{mL}$ after $24 \mathrm{~h}$ suggests that only part of the nanoparticle population suffered aggregation, resulting in heterogeneous size distribution. The size and PDI of nanoLPG diluted in DMEM (3.125 and $25 \mu \mathrm{g} / \mathrm{mL})$ immediately analyzed $(0 \mathrm{~h})$ were comparable to those of freshly prepared nanoLPG. At the highest concentration $(200 \mu \mathrm{g} / \mathrm{mL})$, nanoLPG was outside the accuracy of the DLS, probably because of its high opacity and viscosity when diluted in DMEM.

In summary, these data suggest partial nanoparticle instability under biological conditions, specifically those used in cell culture, which could affect nanoLPG biological activity or biodistribution. Nanoparticle stability can be affected by polymeric head groups of polysorbate 80 , which provides steric stabilization and increase nanoparticle blood circulation time by preventing protein plasma adsorption (Friedrich et al. 2015; Zhu et al. 2019). Although nanoLPG contains polysorbate 80, it seems that the concentration to produce nanoLPG, chosen based on its safe oral daily intake (10-25 mg/kg) (EFSA 2015; Kriegel et al. 2019), was not sufficient to prevent aggregation in biological medium and confer colloidal stability to nanoparticles.

\section{Antioxidant activity evaluation}

The antioxidant activity of nanoLPG was evaluated by the DPPH free radical scavenging capacity and was compared with that of Trolox. NanoLPG at $0.10 \mathrm{mg} / \mathrm{mL}$ exhibited radical scavenging activity equivalent to $0.043 \pm 0.002 \mathrm{mg}$ Trolox $/ \mathrm{mL}$ (or $171.10 \pm 7.41 \mu \mathrm{M}$ Trolox equivalent/g), which is approximately $50 \%$ as effective (Fig. 3). The antioxidant

Table 2 Colloidal stability of nanoLPG diluted in the cell culture medium

\begin{tabular}{|c|c|c|c|c|}
\hline \multirow[t]{2}{*}{ Concentration $(\mu \mathrm{g} / \mathrm{mL})$} & \multicolumn{2}{|l|}{$\mathrm{Oh}$} & \multicolumn{2}{|l|}{$24 \mathrm{~h}$} \\
\hline & Size $(\mathrm{nm})$ & PDI & Size $(\mathrm{nm})$ & PDI \\
\hline 3.12 & $226.90 \pm 3.96$ & $0.26 \pm 0.01$ & $391.20 \pm 33.20^{*}$ & $0.61 \pm 0.01^{*}$ \\
\hline 25 & $256.80 \pm 1.79$ & $0.17 \pm 0.08$ & $359.60 \pm 26.06^{*}$ & $0.17 \pm 0.09$ \\
\hline DMEM & $20.59 \pm 1.43$ & $0.73 \pm 0.10$ & $26.79 \pm 0.73$ & $0.88 \pm 0.03$ \\
\hline
\end{tabular}

Data were expressed as mean \pm SD. ${ }^{*} p<0.05$ vs $0 \mathrm{~h}$ 


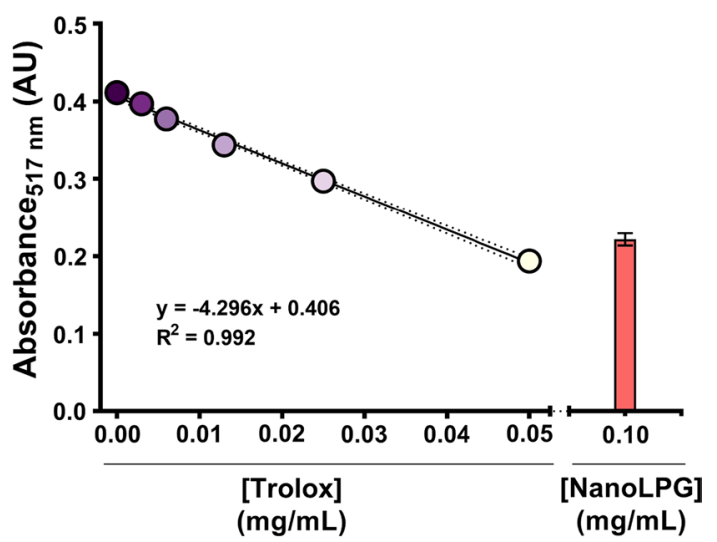

Fig. 3 Antioxidant activity of nanoLPG by the DPPH radical scavenging assay compared to Trolox. Data expressed as mean $\pm \mathrm{SD}$

Table 3 Body and organs weights from Swiss mice treated with a single oral dose of LPG (2,000 mg/ $\mathrm{kg}$ ) and observed for 14 days

\begin{tabular}{llll}
\hline Parameter & Day & Control & LPG \\
\hline Body weight (g) & 0 & $29.26 \pm 3.06$ & $29.54 \pm 3.41$ \\
& 14 & $28.72 \pm 2.64$ & $29.16 \pm 3.38$ \\
Organ weight (g) & & & \\
Heart & 14 & $0.12 \pm 0.01$ & $0.11 \pm 0.02$ \\
Lung & & $0.16 \pm 0.02$ & $0.16 \pm 0.02$ \\
Liver & & $0.99 \pm 0.14$ & $0.95 \pm 0.12$ \\
Kidney & & $0.38 \pm 0.04$ & $0.37 \pm 0.08$
\end{tabular}

Values were expressed as mean \pm SEM. $\mathrm{N}=5$ animals per group

activity of the nanoLPG measured here is consistent with that previously reported for lycopene from red guava (LPG) using the ABTS radical scavenging method, which resulted in 139.52 $\pm 0.30 \mu \mathrm{M}$ Trolox/g (Amorim et al. 2020). Although the results were obtained using different methods, DPPH and ABTS assays showed approximate values and rely on the same antioxidant mechanism (Caetano-Silva et al. 2020). It is possible to suggest nanoLPG to be an antioxidant that acts by the hydrogen donating mechanism, since DPPH radical is an acceptor of hydrogen (Marsup et al. 2020).

\section{In vivo toxicity of LPG and nanoLPG}

The toxicity studies using the free form of LPG did not reveal any deaths or alterations in behavioral and clinical parameters of Swiss mice treated with a single oral dose of LPG at $2000 \mathrm{mg} / \mathrm{kg}$ and observed for 14 days. Furthermore, there were no significant changes in body and organ weights (Table 3). These results indicate the absence of systemic acute toxicity for LPG. Since no animal died, it was not possible to determine the mean lethal dose $\left(\mathrm{LD}_{50}\right)$.

In the repeated-dose oral toxicity study, animals treated with nanoLPG at $10 \mathrm{mg} / \mathrm{kg}$ for 28 days did not exhibit any abnormal clinical features or changes in general behavior when compared with those of water-treated animals (Table 4). No death was recorded in 
Table 4 Effect of nanoLPG on clinical and behavioral parameters

\begin{tabular}{|c|c|c|c|c|c|}
\hline \multirow[t]{2}{*}{ Parameter } & & \multicolumn{2}{|c|}{ Control } & \multicolumn{2}{|c|}{ NanoLPG } \\
\hline & & Day 0 & Day 28 & Day 0 & Day 28 \\
\hline \multirow[t]{5}{*}{ Stimulant } & Hyperactivity & 0 & 0 & 0 & 0 \\
\hline & Agressiveness & 0 & 0 & 0 & 0 \\
\hline & Tremors & 0 & 0 & 0 & 0 \\
\hline & Convulsion & 0 & 0 & 0 & 0 \\
\hline & Piloerection & 0 & 0 & 0 & 0 \\
\hline \multirow[t]{11}{*}{ Depressive } & Ptosis & 0 & 0 & 0 & 0 \\
\hline & Nose bulge & 0 & 0 & 0 & 0 \\
\hline & Cheek bulge & 0 & 0 & 0 & 0 \\
\hline & Ear position & 0 & 0 & 0 & 0 \\
\hline & Whisker change & 0 & 0 & 0 & 0 \\
\hline & Sedation/Anesthesia/Analgesia & 0 & 0 & 0 & 0 \\
\hline & Ataxia & 0 & 0 & 0 & 0 \\
\hline & Righting reflex & 0 & 0 & 0 & 0 \\
\hline & Catatonia & 0 & 0 & 0 & 0 \\
\hline & Loss of corneal reflex & 0 & 0 & 0 & 0 \\
\hline & Loss of auricular reflex & 0 & 0 & 0 & 0 \\
\hline \multirow{5}{*}{$\begin{array}{l}\text { Autonomic nervous system- } \\
\text { related }\end{array}$} & Diarrhea & 0 & 0 & 0 & 0 \\
\hline & Constipation & 0 & 0 & 0 & 0 \\
\hline & Lacrimation & 0 & 0 & 0 & 0 \\
\hline & Salivation/Nomit & 0 & 0 & 0 & 0 \\
\hline & Cyanosis & 0 & 0 & 0 & 0 \\
\hline \multirow[t]{6}{*}{ Others } & Ambutation & 0 & 0 & 0 & 0 \\
\hline & Self-cleaning (grooming) & 0 & 0 & 0 & 0 \\
\hline & Climb & 0 & 0 & 0 & 0 \\
\hline & Vocalization & 0 & 0 & 0 & 0 \\
\hline & Abdominal writhes & 0 & 0 & 0 & 0 \\
\hline & Deaths & 0 & 0 & 0 & 0 \\
\hline
\end{tabular}

$0=$ without effect. $N=9$ animals per group

both treated and control groups. Interestingly, although nanoLPG-treated mice showed no change in the number of grooming movements, they groomed immediately after treatment, whereas mice in the control group took some seconds to engage in grooming after treatment. Self-grooming in rodents is a homeostatic behavior and its decrease can be a marker of anhedonia in front of stressor agents (Butelman et al. 2019). For the OECD (2002b), the failure to self-groom indicates a health disorder, but, in certain

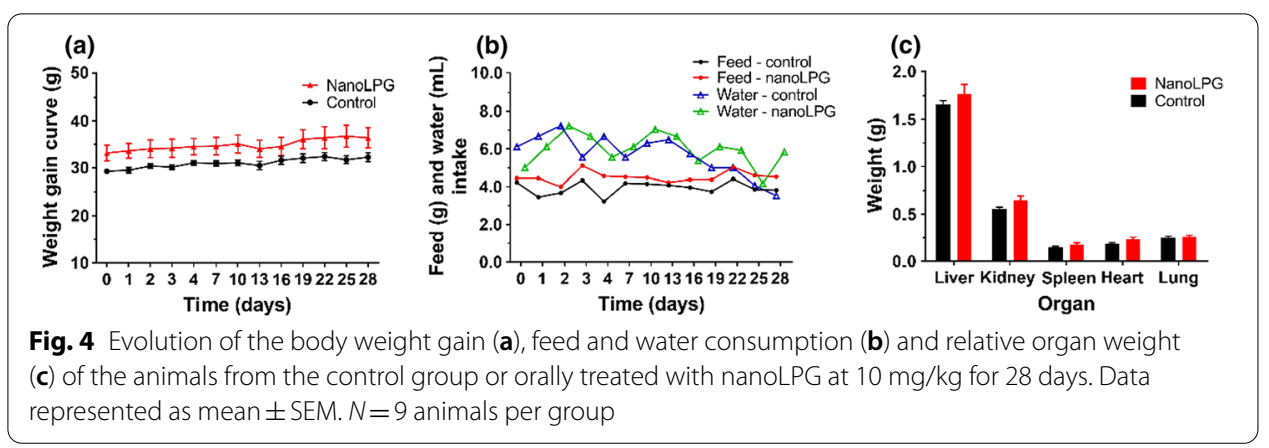


studies, the change in self-grooming is due to the taste of the tested substance. Thus, the immediate grooming might have been caused by the taste of the nanoLPG emulsion.

Body weight gain (Fig. 4a) and feed and water intake (Fig. 4b) of Swiss mice did not differ significantly between nanoLPG-treated mice and the control group over 28 days. The wet weight of selected organs were similar between nanoLPG-treated and water-treated mice (Fig. 4c). Furthermore, the macroscopic analysis of the organs did not detect any morphological alterations in both nanoLPG-treated and control mice. These results indicate the absence of systemic repeated-dose toxicity of nanoLPG orally administered to mice.

Hematological and biochemical parameters are important for monitoring general health conditions, immune response, and tissue injuries induced by a substance. In the present study, the hemogram of nanoLPG-treated mice showed no significant modifications compared with that of the control group (Table 5). This finding suggests that nanoLPG is hemocompatible at the tested experimental conditions. Moreover, there was no significant variation in leukocytes count, indicating that nanoLPG did not provoke leukopenia or leukocytosis in mice after 28 days (Table 5). Another important observation was the absence of band cell in the peripheral blood. Band cells are immature neutrophils that may enter into the circulation in response to acute stress, such as inflammation, tissue damage, or infection, characterizing a phenomenon named neutrophil left shift (Cornbleet 2002). In this context, nanoLPG at $10 \mathrm{mg} / \mathrm{kg}$ did not induce an increase of immature neutrophils in mice after 28 days of treatment.

There was no significant change in the platelet count (Table 5). This is an important observation, since nanoparticle surface charge might disrupt the coagulation system. As demonstrated by Wu et al. (2018) for solid lipid nanoparticles, a cationic surface is associated with an increased risk of systemic platelet activation and aggregation in vivo, reducing blood circulation time and cellular uptake of the nanoparticles. The lack of thrombotic toxicity might be attributed to the negative zeta potential of nanoLPG. Finally, the concentration of total plasma protein was not affected by treatment with

Table 5 Effect of nanoLPG on hematological parameters

\begin{tabular}{|c|c|c|}
\hline Parameter & Control & NanoLPG \\
\hline Hematocrit (\%) & $48.60 \pm 0.51$ & $46.13 \pm 0.85$ \\
\hline Erythrocytes ( $\times 10^{6}$ cells $\left./ \mu \mathrm{L}\right)$ & $09.95 \pm 0.13$ & $09.39 \pm 0.20$ \\
\hline Hemoglobin (g/dL) & $17.72 \pm 0.55$ & $18.14 \pm 1.29$ \\
\hline $\mathrm{MCV}(\mathrm{fL})$ & $48.82 \pm 0.79$ & $49.23 \pm 1.11$ \\
\hline $\mathrm{MCHC}(\%)$ & $36.44 \pm 1.08$ & $39.36 \pm 2.89$ \\
\hline Leukocytes (cells/ $\mu \mathrm{L}$ ) & $5,750 \pm 1096$ & $4,275 \pm 575$ \\
\hline Monocytes (\%) & $2.20 \pm 0.37$ & $2.37 \pm 0.59$ \\
\hline Lymphocytes (\%) & $79.80 \pm 2.15$ & $76.88 \pm 1.96$ \\
\hline Eosinophils (\%) & $0.60 \pm 0.24$ & $0.25 \pm 0.16$ \\
\hline Basophils (\%) & $0.00 \pm 0.00$ & $0.00 \pm 0.00$ \\
\hline Band cell (\%) & $0.00 \pm 0.00$ & $0.00 \pm 0.00$ \\
\hline Segmented neutrophils (\%) & $17.40 \pm 2.31$ & $20.50 \pm 2.03$ \\
\hline Platelets (cells/ $\mu \mathrm{L}$ ) & $800,000 \pm 107,165$ & $897,250 \pm 66,576$ \\
\hline Total plasmatic proteins (g/dL) & $6.56 \pm 0.29$ & $6.85 \pm 0.88$ \\
\hline
\end{tabular}

Data were expressed as mean \pm SEM. MCV: mean corpuscular volume. MCHC: mean corpuscular hemoglobin concentration. $N=5-9$ animals per group 
Table 6 Effect of nanoLPG on biochemical parameters

\begin{tabular}{lcc}
\hline Parameter & Control & NanoLPG \\
\hline Glicose $(\mathrm{mg} / \mathrm{dL})$ & $215.90 \pm 9.74$ & $238.60 \pm 11.18$ \\
Cholesterol $(\mathrm{mg} / \mathrm{dL})$ & $127.00 \pm 3.57$ & $128.70 \pm 5.12$ \\
Triglycerides $(\mathrm{mg} / \mathrm{dL})$ & $130.70 \pm 16.06$ & $152.60 \pm 27.29$ \\
Urea $(\mathrm{mg} / \mathrm{dL})$ & $42.75 \pm 2.46$ & $49.02 \pm 2.47$ \\
Creatinine $(\mathrm{mg} / \mathrm{dL})$ & $0.42 \pm 0.04$ & $0.33 \pm 0.04$ \\
ALT $($ U.I./L) & $68.67 \pm 10.16$ & $55.63 \pm 6.96$ \\
AST (U.I./L) & $339.40 \pm 51.42$ & $272.30 \pm 28.56$ \\
ALP (U.I./L) & $101.02 \pm 5.94$ & $89.28 \pm 10.64$
\end{tabular}

Data were expressed as mean \pm SEM. ALT alanine aminotransferase. AST aspartate aminotransferase. ALP alkaline phosphatase. $N=5-9$ animals per group

nanoLPG for 28 days (Table 5). Changes in blood protein levels are usually associated with fluctuations in albumin and globulin levels as a result of disorders in the immune system and liver and kidney injuries (Ghelichpour et al. 2017).

In addition, glucose, total cholesterol, and triglycerides levels in blood did not differ significantly between nanoLPG-treated mice and the control group (Table 6). The levels of biomarkers for kidney injury, urea and creatinine, were unaffected by nanoLPG treatment, indicating the lack of nephrotoxicity in nanoLPG-treated mice (Table 6). These findings are especially relevant considering that nanoparticles circulating in the bloodstream should pass through the renal vasculature (Du et al. 2018). Compared with the control group, nanoLPG-treated mice presented a general tendency of decreasing levels of liver function markers (ALT, AST and ALP) (Table 6). However, the difference in the levels of these markers between the groups did not reach statistical significance, indicating the occurrence of a normal fluctuation and not a physiological finding. In summary, the nanoemulsion loaded with lycopene purified from red guava did not cause physiological alterations that could indicate in vivo toxicity. The toxicity of nanoparticles is a critical factor for the biological application of drug delivery systems and needs to be comprehensively explored prior to further in vivo studies.

\section{Histopathological analysis}

The histopathological analysis of the brain, aorta, heart, lung, liver, spleen, kidney, stomach, esophagus, small intestine, large intestine, and pancreas revealed that the oral administration of nanoLPG at $10 \mathrm{mg} / \mathrm{kg}$ for 28 days did not induce pathological alterations with clinical significance in Swiss mice (Fig. 5). Minor histological alterations were observed in the liver, such as diffuse hydropic degeneration in hepatocytes (yellow arrow). The hydropic or vacuolar degeneration could be the result of the disruption of hepatocyte osmoregulatory balance, increasing the intracellular water (Susilo et al. 2019). It is worth mentioning that this is a reversible and nonlethal acute injury. Overall, the histopathological observations are consistent with the clinical, biochemical and hematological data.

\section{Tissue distribution}

The biodistribution of lycopene from the orally administered nanoLPG into tissues was evaluated by HPLC in the brain, heart, lung, liver, spleen, kidney, and prostate samples 


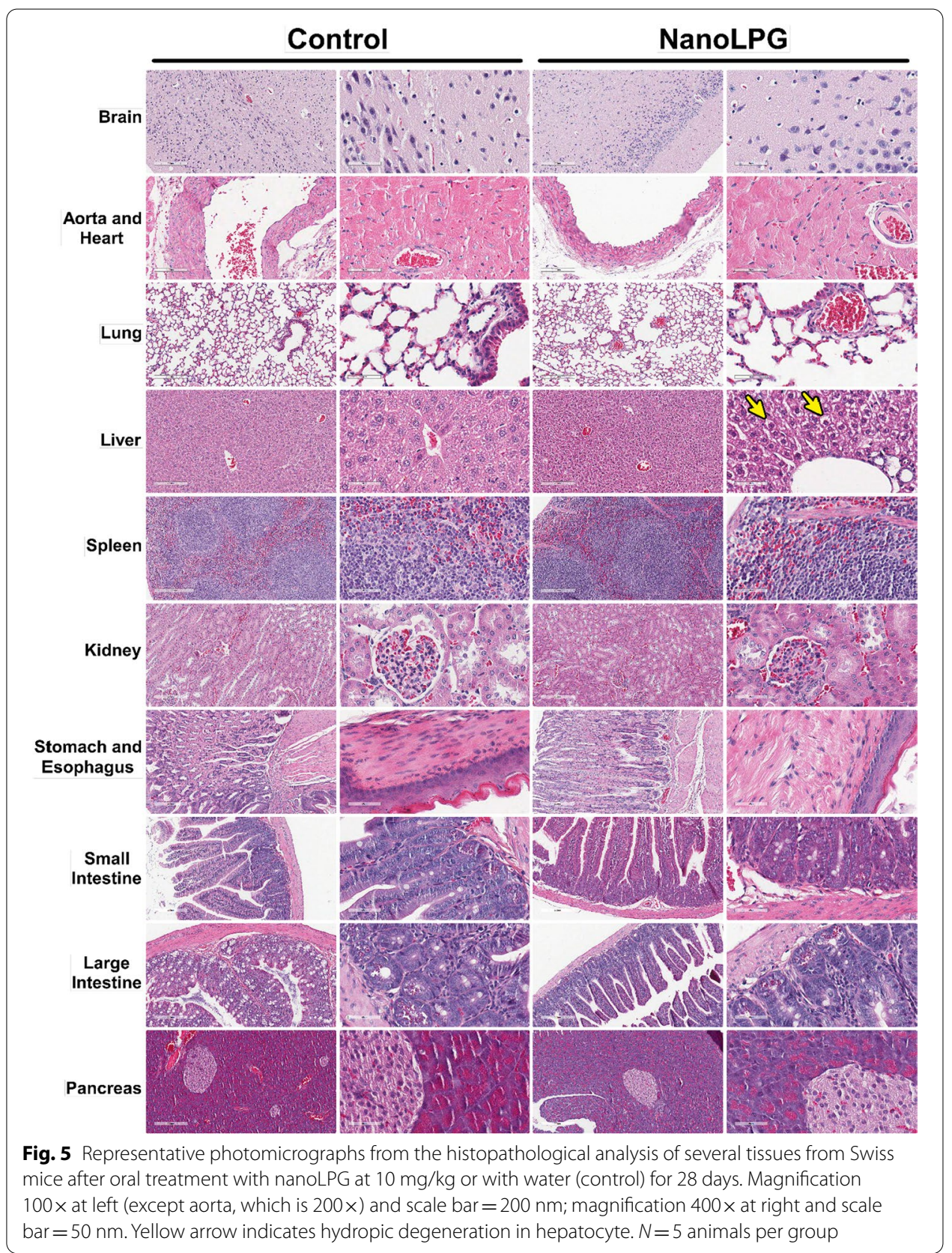

from mice treated daily with $10 \mathrm{mg} / \mathrm{kg}$ for 28 days. Lycopene was detected in the prostate $(0.0320 \pm 0.0070 \mu \mathrm{g} / \mathrm{g})$, kidney $(0.1118 \pm 0.0239 \mu \mathrm{g} / \mathrm{g})$, and liver $(0.1829 \pm 0.0927 \mu \mathrm{g} / \mathrm{g})$ (Fig. 6), whereas it was not detected in other organs of nanoLPG-treated mice and in any organ of mice in the control group. As demonstrated in human and animal studies, intact lycopene can accumulate in various tissues, such as the liver, adrenal glands, spleen, lungs, prostate gland, colon, and skin (Srivastava and Srivastava 2015; Mirahmadi et al. 2020; Wang 2012).

Lycopene concentration in the prostate was comparable to that reported in other studies. For example, lycopene content in the prostate of mice fed with a diet supplemented with commercial lycopene to provide $150 \mathrm{mg} / \mathrm{kg}$ for 60 days was $0.81 \pm 0.08 \mathrm{nmol} / \mathrm{g}$ 


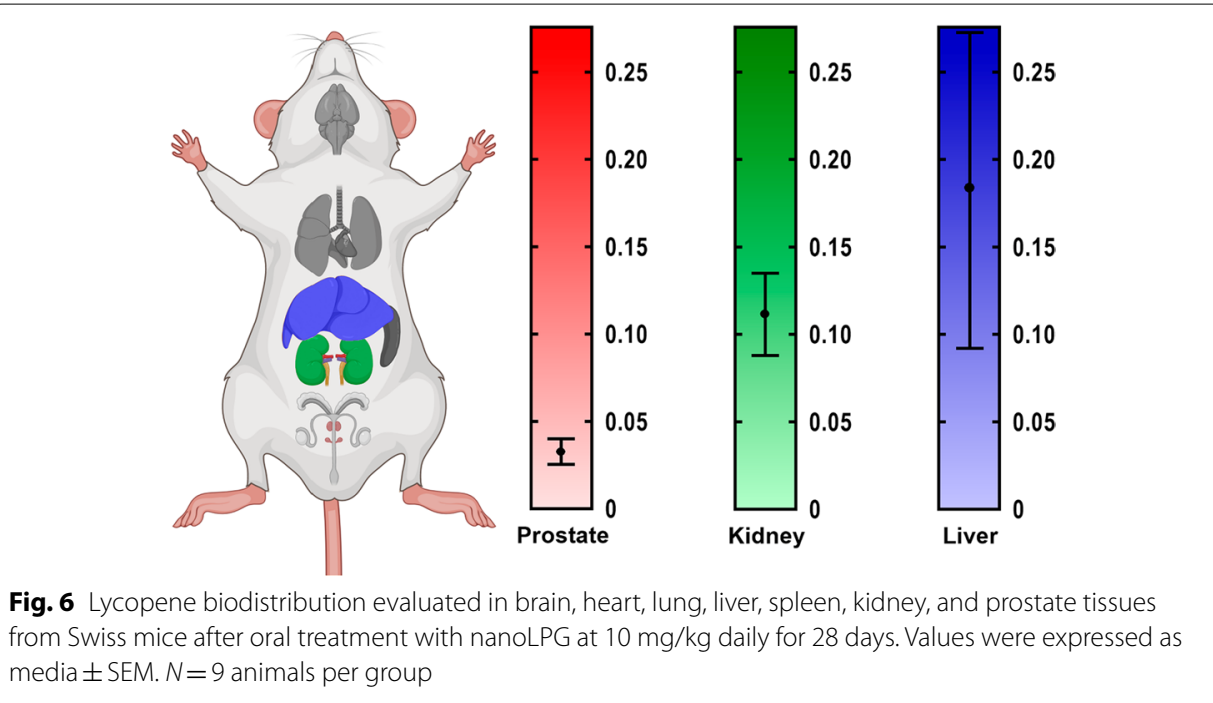

(equivalent to $0.4349 \mu \mathrm{g} / \mathrm{g}$ ) (Lindshield et al. 2008). Note that the lycopene level was thirteen times greater than that found in this work, but the dose was fifteen times higher than the dose used in the present study. In the prostate of rats treated with tomato oleoresin extract at $4.6 \mathrm{mg} / \mathrm{kg}$ for 9 weeks, the concentration of lycopene was $24 \pm 10.3 \mathrm{nmol} /$ $\mathrm{kg}$ (equivalent to $0.0129 \mu \mathrm{g} / \mathrm{g}$ ) (Ferreira et al. 2000). Consistently, lycopene levels were approximately half the concentration found in the present work, which was achieved by administering half the dose applied in the present study. Thus, the efficiency of the oral administration of nanoLPG in delivering lycopene into the prostate corresponds to that of other sources of lycopene.

The presence of lycopene in the kidney can be the consequence of having lycopeneloaded nanoparticles in the bloodstream, including the renal vasculature, although the literature reports the lycopene accumulation via the scavenger receptor class B type 1 protein (SR-B1) found in this tissue (Wang 2012). The concentration of lycopene in the liver tends to be higher than that in other organs. The evaluation of tissue distribution of orally administered lycopene at $30 \mathrm{mg} / \mathrm{kg}$ in male dogs revealed that the highest concentration of lycopene was detected in the liver with 1 and 5 days after the 28-day dosing period (65.6 and $91.0 \mathrm{nmol} / \mathrm{g}$, respectively) (Korytko et al. 2003), in consonance with the found in this study.

Nanoparticle biodistribution for delivery of bioactive compounds can be influenced by its hydrodynamic diameter (Kaga et al. 2017). Baranowska-Wójcik et al. (BaranowskaWójcik et al. 2020) reported the effect of different sizes of titanium dioxide nanoparticles on biodistribution after a single oral administration and showed that larger particles (>80 nm) mainly accumulated in the liver. Consistently, Kaga et al. (Kaga et al. 2017) described that large polymeric nanoparticles were rapidly biodistributed into the liver and spleen. Although the pharmacokinetic parameters of nanoLPG were not evaluated here, the data show that nanoLPG successfully deliver lycopene to the tissues. Besides, lycopene accumulation in tissues has been reported to prevent various diseases, such as prostate cancer, cholestasis, steatosis, inflammation, alcoholic liver disease (Stice et al. 2018; Wadie et al. 2020). 


\section{Cytotoxic effect on prostate cancer cells}

Since lycopene accumulated in the prostate of nanoLPG-treated mice, we advanced the study towards the evaluation of the cytotoxicity of the nanoemulsion on the human prostate carcinoma cell line (DU-145). The MTT assay demonstrated that the treatment with free LPG significantly affected cell viability after $6 \mathrm{~h}$ of exposure even at the lowest concentration $(3.125 \mu \mathrm{g} / \mathrm{mL})$, with a reduction of $19.33 \pm 2.36 \%$ (Fig. 7a). Similarly, nanoLPG significantly reduced DU-145 viability after $6 \mathrm{~h}$ of exposure at $3.125 \mu \mathrm{g} / \mathrm{mL}$, presenting $44.65 \pm 6.90 \%$ of reduction (Fig. $7 \mathrm{~b}$ ). Note that the nanoemulsion increased the deleterious effect of free LPG on prostate cancer cells. Such effect is also evident in the $\mathrm{IC}_{50}$ values, which were markedly lower for nanoLPG than free LPG at all times (Fig. 7c). In addition, the $\mathrm{IC}_{50}$ values gradually decreased over time until $48 \mathrm{~h}$ (Fig. 7c). The maximum effects of free LPG and nanoLPG were observed at $72 \mathrm{~h}$ of exposure at $200 \mu \mathrm{g} / \mathrm{mL}$ ( $93.20 \pm 0.31 \%$ and $100 \pm 3.32 \%$ of viability reduction, respectively). However, after the $48 \mathrm{~h}$ of exposure, the difference in cytotoxic effect was not statistically significant for both samples.

Free LPG at $0.75 \mu \mathrm{g} / \mathrm{mL}$ significantly affected PBMC viability with $24 \mathrm{~h}$ of exposure (Fig. 7d), while nanoLPG was not significantly cytotoxic (Fig. 7e) $(13.43 \pm 1.13 \%$ and $6.36 \pm 3.43 \%$ of viability reduction at $25 \mu \mathrm{g} / \mathrm{mL}$, respectively). Note that the tested

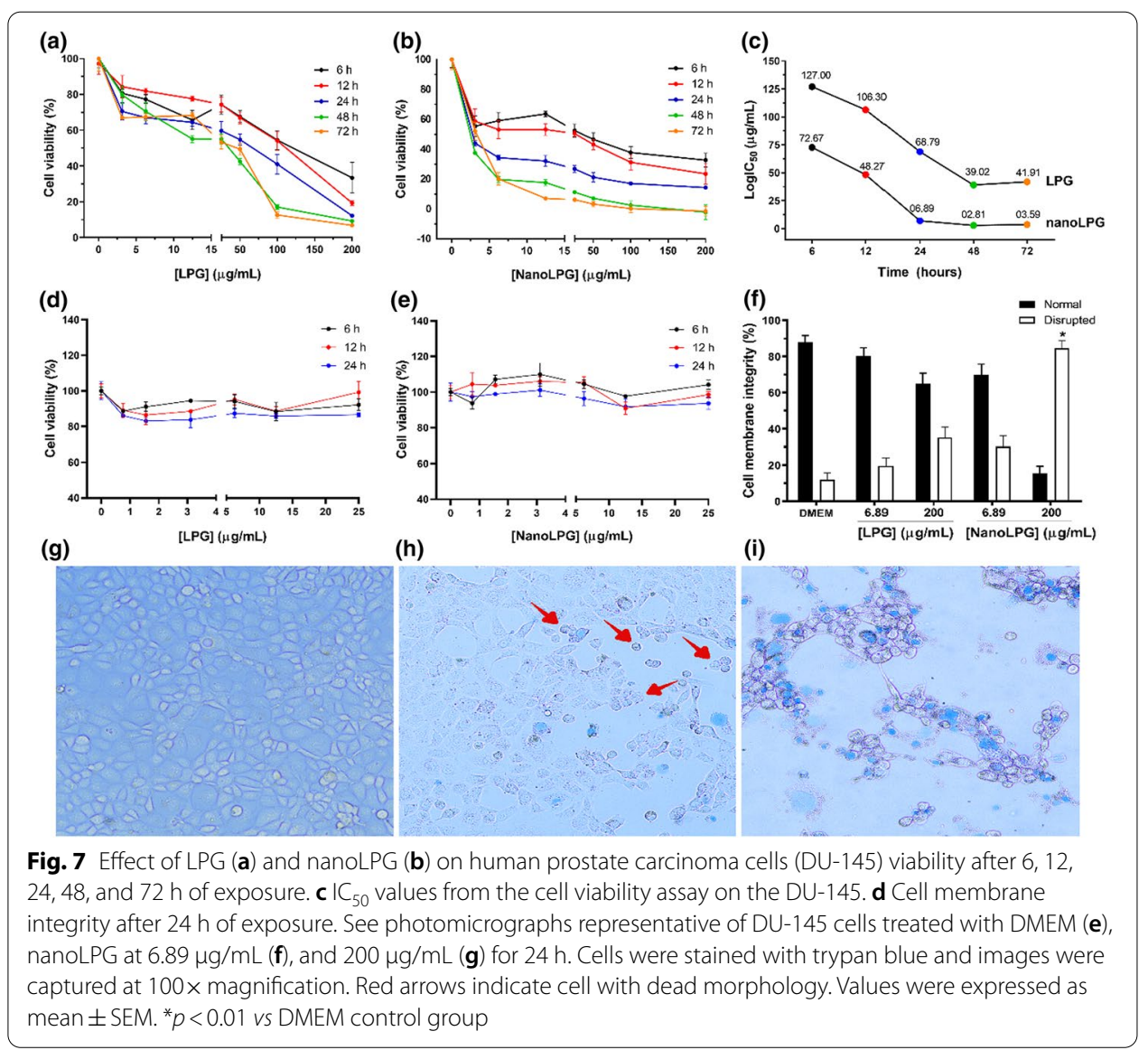


concentration of nanoLPG on PBMC is three times higher than $\mathrm{IC}_{50}$ values to DU-145, suggesting a selective cytotoxic action for the prostate cancer cells.

The mechanism underlying the effects of nanoLPG on DU-145 cells was further investigated using the following experimental conditions: nanoLPG at its $\mathrm{IC}_{50}(6.89 \mu \mathrm{g} / \mathrm{mL})$ and at the highest previously tested concentration $(200 \mu \mathrm{g} / \mathrm{mL})$ and $24 \mathrm{~h}$ of exposure. The analysis of cell membrane integrity by trypan blue staining showed that free LPG (6.89 and $200 \mu \mathrm{g} / \mathrm{mL}$ ) did not disrupt membrane integrity after $24 \mathrm{~h}$ of exposure as compared with DMEM control (Fig. 7f). This result corroborates those found by Dos Santos et al. (Santos et al. 2018) for a lycopene-rich extract from red guava (LEG) on MCF-7 cells.

The treatment with nanoLPG caused statistically significant damage on cell membrane only at $200 \mu \mathrm{g} / \mathrm{mL}$ (Fig. 7f). Trypan blue stains nonviable cells with a blue color due to disruption of the membrane, while undamaged cells appear unstained (Crowley et al. 2016a). Note that in the photomicrographs control cells fail to uptake the dye (Fig. $7 \mathrm{~g}$ ), cells treated with nanoLPG at $6.89 \mu \mathrm{g} / \mathrm{mL}$ were unstained despite many of them had a dead cell morphology (red arrows, Fig. 7h), whereas the cells treated with nanoLPG at $200 \mu \mathrm{g} / \mathrm{mL}$ were clearly stained with trypan blue (Fig. 7i). This result shows that the nanoemulsion at high concentrations affects membrane integrity.

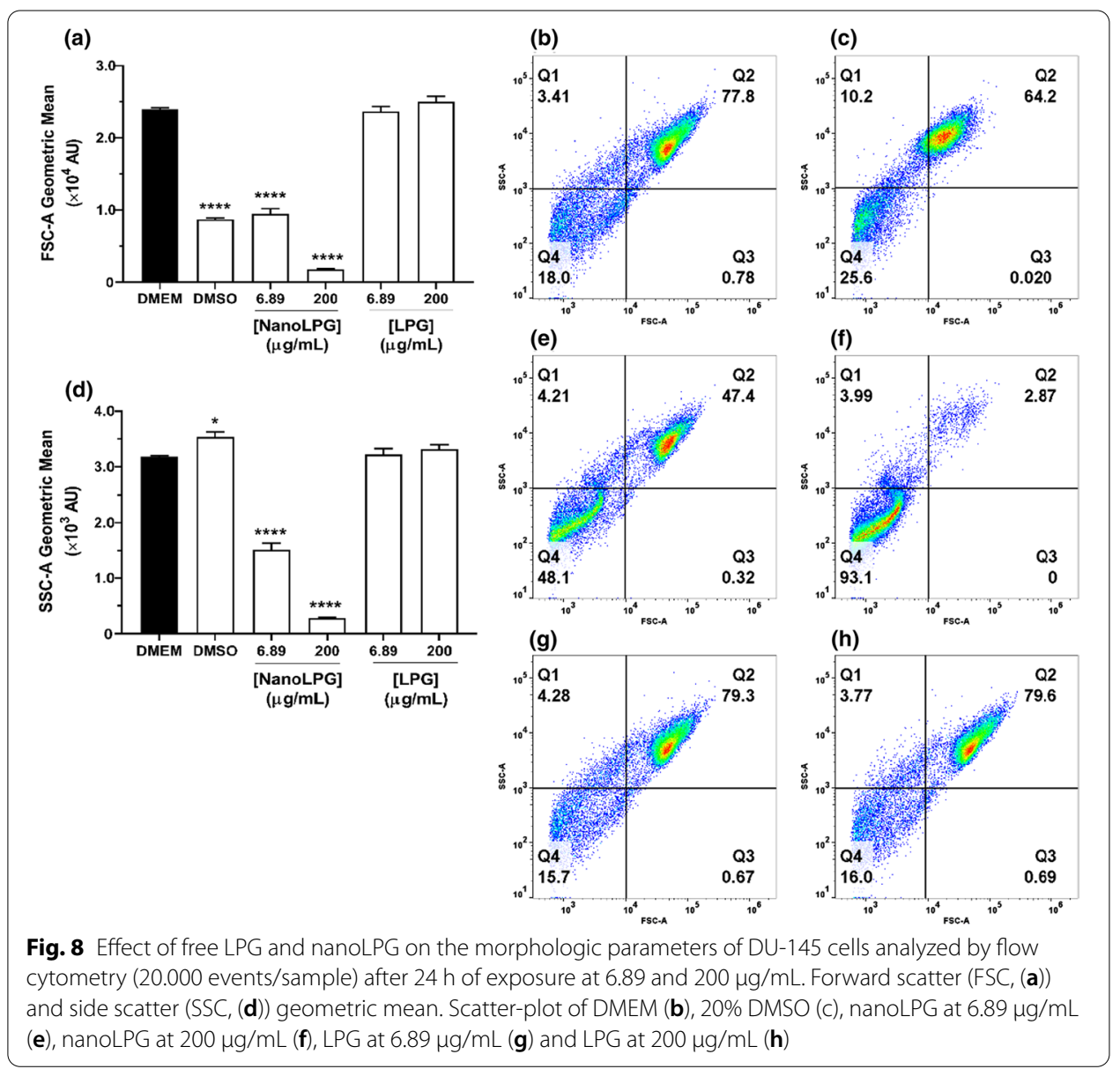


Moreover, flow cytometry analysis of DU-145 cells revealed that nanoLPG at 6.89 and $200 \mu \mathrm{g} / \mathrm{mL}$ induced expressive morphological alterations (Fig. 8a, d, e, and f)). There was a significant $(p<0.05)$ reduction in both forward light scatter (FSC, Fig. 8a) and side light scatter (SSC, Fig. 8d), indicating a decrease in cell size and granularity, respectively. These morphological alterations suggest cell membrane rupture and release of cytoplasmatic content. Such events, also observed in the trypan blue assay, are typical of necrotic cell death. No significant morphological changes were found in cells treated with free LPG (Fig. 8a, d, g and h) when compared to control cells treated with DMEM (Fig. 8a, b and d), which may be related to a low percentage of dead cells in this assay. Cells treated with $20 \%$ DMSO as a cell death control group (Fig. 8a, c and d) exhibited a decrease in FSC and increase in SSC indicative of cell shrinkage that occurs in apoptosis.

The analysis of DU-145 by flow cytometry using annexin-V FITC/propidium iodide is shown in Fig. 9. Cells treated with DMSO exhibited an increase in PI and annexin-V fluorescence intensity, which are suggestive of late apoptosis (Fig. 9b). Annexin-V has a strong affinity for phosphatidylserine, whose presence in the external layer of the plasmatic membrane is a marker of apoptosis. Thus, annexin- $\mathrm{V}$ has been commonly used as a marker for the initial phase of the traditional apoptotic pathway (Santos et al. 2018; Crowley et al. 2016b). Propidium iodide (PI) is a fluorogenic compound that binds to nucleic acids, usually used to label necrotic cells (Crowley et al. 2016b). Since the cells treated with nanoLPG (Fig. 9c, d) were not significantly labeled with annexin- $\mathrm{V}$, the mechanism of cell death caused by the nanoemulsion was not traditional apoptosis. However, PI staining was not also statistically different when compared to the DMEM control group (Fig. 9a), although the above-mentioned assays (trypan blue, FSC and SSC) indicate a component of necrosis for nanoLPG. Thus, we hypothesize that the mechanism underlying the effects of nanoLPG on DU-145 cells may not be classic necrosis. Apoptosis is characterized as an organized cell death, resulting in clearance of cells with minimal damage to tissues, while necrosis is traditionally a passive and traumatic form of cell death with subsequent damage to surrounding tissues (D'Arcy 2019). However, under certain circumstances, necrosis can occur in a highly regulated manner, such as in parthanatos, necroptosis, pyroptosis, among others (Lu et al. 2021; Nirmala and Lopus 2020). Evaluating the cell death mechanism may be important to obtain more accurate information about the effect of LPG and nanoLPG, to better understand the safety and efficacy of the product, and generate data that can support further product optimization.

Cells treated with free LPG (6.89 and $200 \mu \mathrm{g} / \mathrm{mL}$ ) did not exhibit an increase in PI and/or annexin-V fluorescence intensity (Fig. 9e, f), which may be related to a low percentage of dead cells in this assay. Dos Santos et al. (Santos et al. 2018) showed that a lycopene-rich extract from red guava (LEG) was cytotoxic to human breast cancer cells (MCF-7) via induction of an apoptotic-like pathway. Several in vitro and in vivo studies describe the effects of lycopene on prostate cancer. Mirahmadi et al. (2020) recently revised that the anti-cancer activity of lycopene against prostate cancer cells was mainly mediated by inhibiting cell proliferation, inducing apoptosis, arresting cell cycle, controlling metastatic phase, and up or down-regulating signaling molecules and transcription factors. However, the specific cell death mechanism of LPG and nanoLPG on prostate cancer cells still warrants further research. 

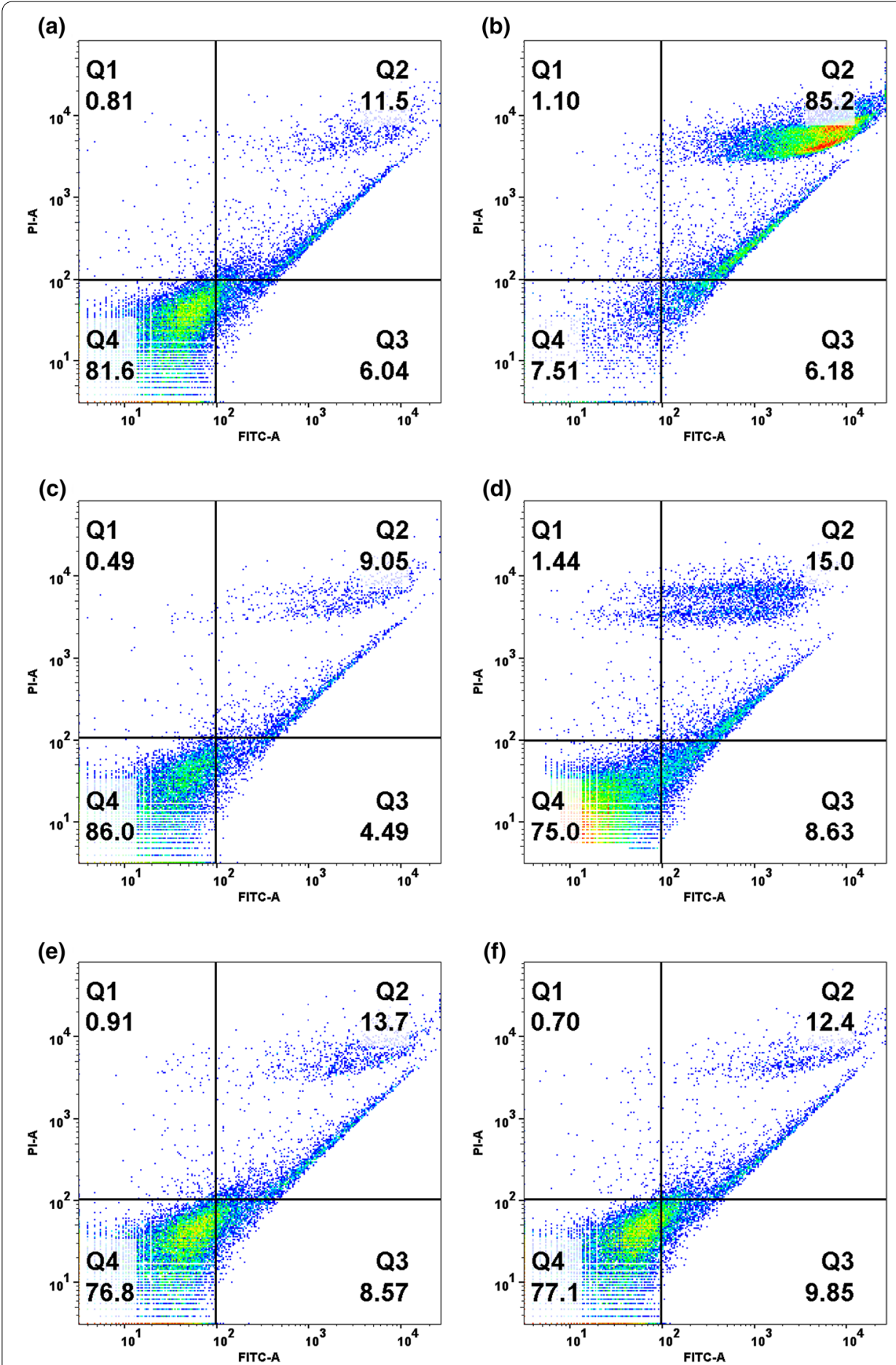

Fig. 9 Analysis by flow cytometry (20.000 events/sample) of DU-145 cells treated with free LPG and nanoLPG after $24 \mathrm{~h}$ of exposure at 6.89 and $200 \mu \mathrm{g} / \mathrm{mL}$ using annexin-V FITC/propidium iodide staining. DMEM (a), 20\% DMSO (b), nanoLPG at $6.89 \mu \mathrm{g} / \mathrm{mL}(\mathbf{c})$, nanoLPG at $200 \mu \mathrm{g} / \mathrm{mL}(\mathbf{d}), \mathrm{LPG}$ at $6.89 \mu \mathrm{g} / \mathrm{mL}(\mathbf{e})$ and LPG at $200 \mu \mathrm{g} /$ $\mathrm{mL}(\mathbf{f})$ 

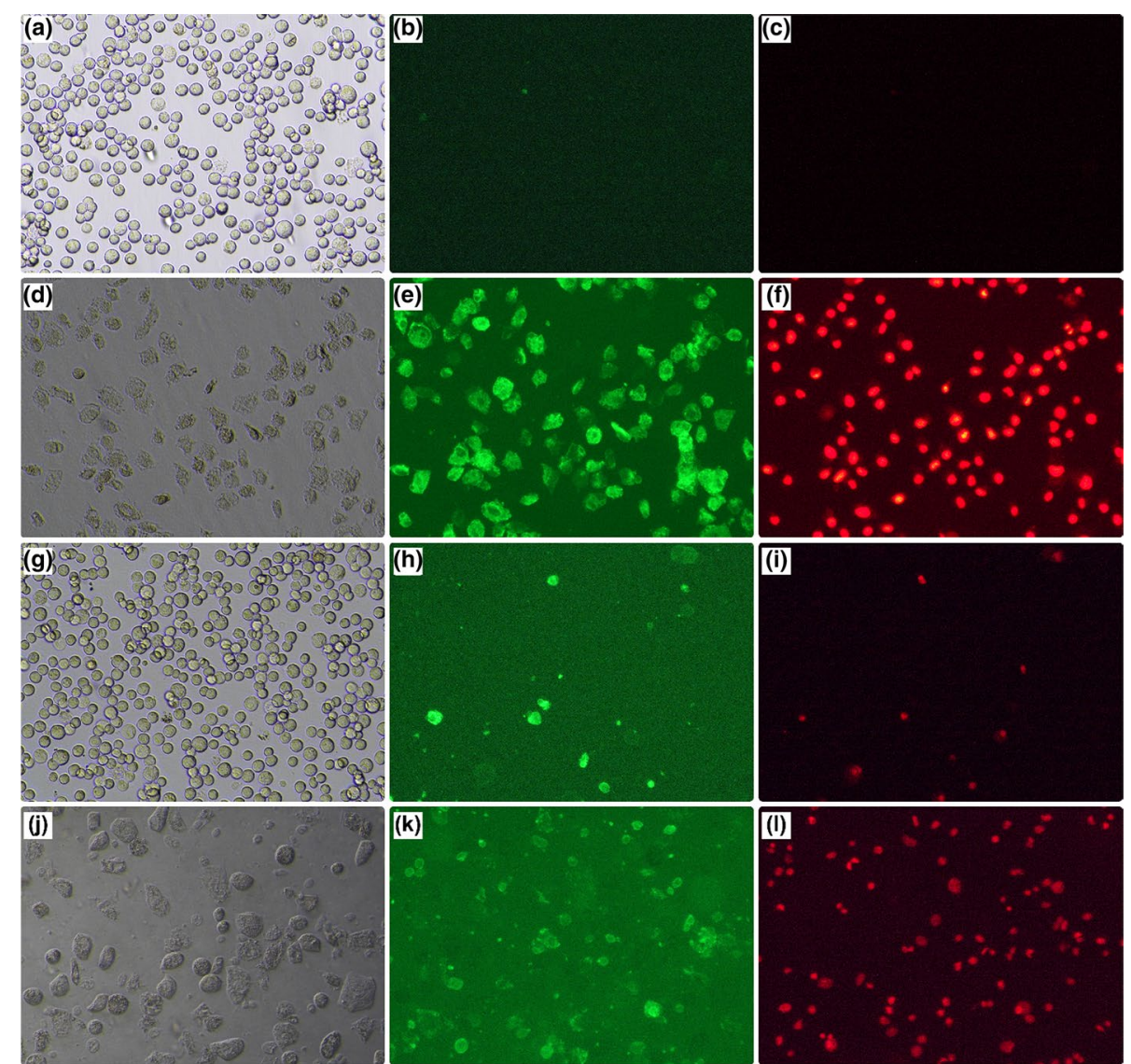

Fig. 10 Photomicrographs from fluorescence microscopy representative of DU-145 cells treated with DMEM $(\mathbf{a}-\mathbf{c})$, DMSO (d-f), LPG at $200 \mu \mathrm{g} / \mathrm{mL}(\mathbf{g}-\mathbf{i})$, and nanoLPG at $200 \mu \mathrm{g} / \mathrm{mL}(\mathbf{j}-\mathbf{l})$ for $24 \mathrm{~h}$. Cells were stained with Annexin-V FITC/propidium iodide and images were captured at $200 \times$ magnification. Left: phase-contrast images; middle: annexin-V FITC staining; right: propidium iodide staining

The fluorescently labeled cells were also analyzed on an inverted microscope under visible or fluorescent light. In the DMEM control group, cells exhibited a well-defined cytoplasmic contour (Fig. 10a) and were not labeled with either annexin-V (Fig. 10b) or PI (Fig. 10c). In contrast, cells treated with DMSO had characteristics of cell injury, such as an increase of granularity, loss of well-defined contour, and retraction (Fig. 10d). Moreover, DMSO-treated cells were clearly stained with both fluorescent cell death markers, annexin-V (Fig. 10e) and PI (Fig. 10f), characterizing late apoptosis. Cells treated with free LPG at $200 \mu \mathrm{g} / \mathrm{mL}$ had a general appearance similar to that of DME-treated control cells (Fig. 10g), with very few cells labeled by annexin-V (Fig. 10h) or PI (Fig. 10i). Cells treated with nanoLPG at $200 \mu \mathrm{g} / \mathrm{mL}$ presented a set of morphological changes that suggested cell death. These cells also presented higher fluorescence intensity than that of LPG-treated cells, but lower than that of cells treated with DMSO (Fig. 10j-l). Overall, the results support those from the necrosis/apoptosis assay by flow cytometry.

Ultrastructural alterations of DU-145 cells treated with free LPG and nanoLPG were visualized by TEM, which provides additional information about the mechanism underlying the effects of the nanoemulsion on prostate cancer cells. Control cells (Fig. 11a) had their surfaces with some microvilli (blue arrowhead), abundant endoplasmic reticulum 

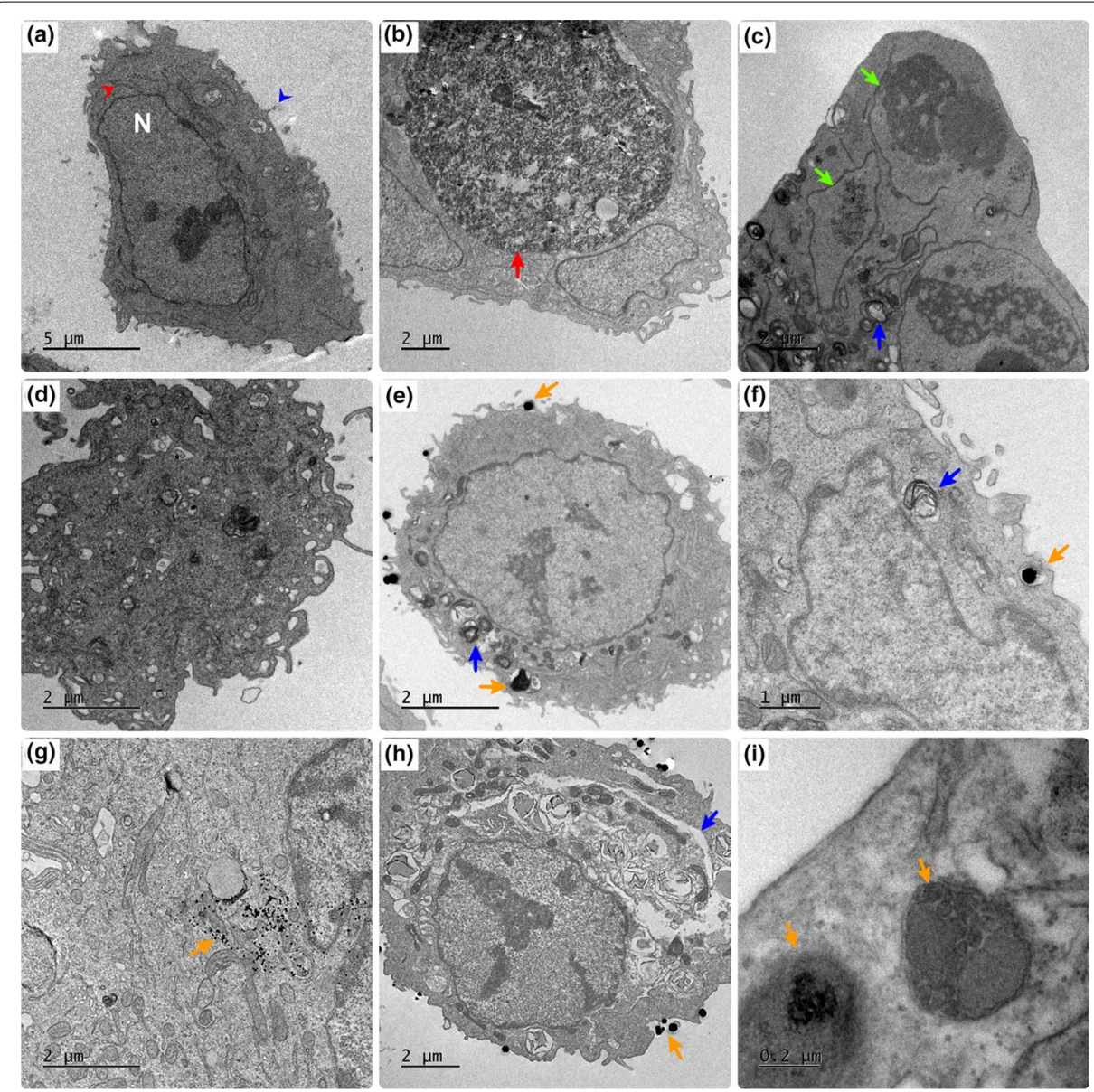

Fig. 11 Representative micrographs from transmission electron microscopy (TEM) of DU-145 cells treated with DMEM (a), LPG at $6.89 \mu \mathrm{g} / \mathrm{mL}(\mathbf{b}, \mathbf{c})$ and $200 \mu \mathrm{g} / \mathrm{mL}(\mathbf{d})$, and nanoLPG at $6.89 \mu \mathrm{g} / \mathrm{mL}(\mathbf{e}, \mathbf{f}, \mathbf{g})$ and $200 \mu \mathrm{g} / \mathrm{mL}$ (h, i) for $24 \mathrm{~h}$. $\mathrm{N}=$ nucleus. Blue arrowhead = microvilli, red arrowhead = endoplasmic reticulum, red arrow $=$ digestion area, green arrow $=$ apoptotic area, blue arrow $=$ necrosis focus and orange arrow $=$ nanoLPG

(red arrowhead) and oval nucleus (N); these features compose the basal aspect of the DU-145 cell line (Stone et al. 1978). Cells treated with free LPG at $6.89 \mu \mathrm{g} / \mathrm{mL}$ exhibited some ultrastructural alterations, such as initial cellular digestion (red arrow, Fig. 11b) and necrosis focus (blue arrow, Fig. 11c), but with membranous structures delimiting cellular compartments (green arrow, Fig. 11c) that are suggestive of apoptosis. Necrotic and apoptotic components (Fig. 11c) can be seen in a single cell in the group of cells treated with LPG. Figure 11d shows the morphology of the cells treated with LPG at $200 \mu \mathrm{g} / \mathrm{mL}$, exhibiting diffuse intracellular digestion, vacuolized aspect, dissolution of nuclear membrane and irregular cytoplasmic contour, but there is no signal of abrupt disruption of cell membrane. Cells treated with nanoLPG at $6.89 \mu \mathrm{g} / \mathrm{mL}$ showed necrosis focus (blue arrow, Fig. 11e, f) and a vacuolized aspect (Fig. 11e). Necrosis foci were also observed in cells treated with nanoLPG at $200 \mu \mathrm{g} / \mathrm{mL}$, where necrosis foci were associated with cytoplasmic swelling (blue arrow, Fig. 11h), but without visible damage on cell membrane. The absence of abrupt damage on cell membrane corroborates 
the observation of few cells labeled with PI in the fluorescence assays. In brief, these morphological alterations indicate that nanoLPG induced cell death in DU-145 through non-classical necrosis, corroborating the cytometry data. Golla et al. (2021), evaluated necroptotic cell death using TEM and described that a typical visual pattern of this type of cell death include swollen cells, enlarged mitochondria, globular vacuoles, rupture of cell membrane and leakage of cellular contents. Despite similarities, additional studies are required to confirm the cell death mechanism induced by the nanoemulsion developed in the present study.

Furthermore, TEM images are evidence of the interaction and internalization of nanoLPG. The orange arrows indicate that nanoLPG was bound to the cell membrane (Fig. 11e, h), internalized into endosome (Fig. 11e, f) and fragmented in an endolysosome (Fig. 11i). Interestingly, nanoparticle fragments can be seen in the cytoplasm or associated with cell endomembrane systems (Fig. 11g), as well as forming a nano-scale spheroids rearrangement in the cell (Fig. 11i). This may be related to lipid character of the nanoparticles and lycopene.

\section{Conclusion}

In the present study, a novel self-emulsifying drug delivery system containing lycopene purified from red guava (nanoLPG) was successfully produced. Considering that lycopene is extracted from guava with a high degree of maturation (a fruit with low commercial value, often destined for disposal), this product adds value to the fruit and can generate a more sustainable production chain. The nanostructuring method is fast, uses mild conditions of agitation and temperature, which interfere less with the stability of the loaded molecule during production, and is industrially scalable. The produced formulation, nanoLPG, had nanoparticles with average size of approximately $200 \mathrm{~nm}$, negative zeta potential and spherical morphology. Lycopene loaded in these nanoparticles was stable for 10 months stored at $5{ }^{\circ} \mathrm{C}$. NanoLPG exhibited the expected antioxidant activity in vitro and had no deleterious effects on clinical, behavioral, hematological, biochemical, and histopathological parameters of mice treated for 28 days. In addition, orally administered nanoLPG successfully delivered lycopene into the liver, kidney, and prostate of mice. NanoLPG improved lycopene cytotoxicity towards DU-145 prostate cancer cells probably by inducing a cell death pathway that is independent on classical necrosis and apoptosis. Taken together, these results indicate that nanoLPG is a viable and safe candidate for the lycopene delivery system as a nanotechnology-based health product.

\footnotetext{
Acknowledgements

We would like to thank the Laboratory of Food, Drug \& Cosmetics (LTMAC) of the University of Brasilia (UnB) for providing the equipment Zetasizer NanoZS90 (Malvern, UK), Laboratory of Molecular Pathology of Cancer of the UnB for the contribution of some resources to cell culture and Bioprospectum, Lda (UPTEC, Porto, Portugal) for the logistical support in receiving the sample in Portugal. A. G. Vasconcelos is grateful to Maíra B. de Oliveira for supporting the maintenance and euthanasia of the animals and Eryka O. De Andrades for sending the raw material (Red Guava) from Piauí to Brasília.

Authors' contributions

AGV and JRSAL designed the project AGV, ALANB, WFC, DCM, IGMS, AESC, MPA, LFFA, RCS, AKSB, FSA, DDRA, MCCM, TKSB, SNB, AP, and PE performed the experiments DCM, SASK, IGMS provided technical support. AGV, DCM, TKSB, SNB, PE, JRSAL wrote the manuscript. AP, PE, SASK, and JRSAL supervised the project. All authors read and approved the final manuscript.

Funding

This study was supported in part by the Coordenação de Aperfeiçoamento de Pessoal de Nível Superior (CAPES, Brazil),
} Project number 1713871. This work also received financial support from PT national funds (FCT/MCTES, Fundação para a 
Ciência e Tecnologia and Ministério da Ciência, Tecnologia e Ensino Superior) through the project UIDB/50006/2020. A.P. is a recipient of a post-doctoral grant from the project PTDC/BII-BIO/31158/2017.

Availability of data and materials

The data sets used and/or analyzed during the study are available from the corresponding author on reasonable request.

\section{Declarations}

Ethics approval and consent to participate

All animal experiments were performed by following the protocol approved by the institutional animal care and use committee at University of Brasília, UnB, Brazil.

\section{Consent for publication}

Not applicable.

\section{Competing interests}

The authors declare that they have no competing interests.

\section{Author details}

${ }^{1}$ Núcleo de Pesquisa Em Morfologia E Imunologia Aplicada, Área de Morfologia, Faculdade de Medicina, Universidade de Brasília, UnB, Campus Universitário Darcy Ribeiro, Asa Norte, Brasília, NuPMIADF 70910900, Brazil. 2 Laboratório de Microscopia E Microanálise, Instituto de Ciências Biológicas, Universidade de Brasília, UnB, Brasília, DF, Brazil. ${ }^{3}$ Laboratório de Hematologia E Células-Tronco, Faculdade de Ciências da Saúde, Universidade de Braślia, UnB, Brasília, DF, Brazil. ${ }^{4}$ LAQV/ REQUIMTE, Departamento de Química E Bioquímica, Faculdade de Ciências da Universidade Do Porto, Porto, Portugal. ${ }^{5}$ Núcleo de Pesquisa Em Biodiversidade E Biotecnologia, Universidade Federal Do Delta Do Parnaíba, UFDPar, BiotecParnaíba, PI, Brazil. ${ }^{6}$ Departamento de Biofísica e Fisiologia, Universidade Federal do Piauí, UFPI, Teresina, PI, Brazil. ${ }^{7}$ The Bridge, School of Chemistry, Joseph Banks Laboratories, University of Lincoln, Lincoln, UK.

Received: 5 July 2021 Accepted: 26 October 2021

Published online: 07 November 2021

\section{References}

Aliyu A, Kabiruyunusa A, Abdullahi N (2020) Kinetics of the thermal degradation of lycopene in tomatoes. Croat J Food Sci Technol 12:84-89. https://doi.org/10.17508/CJFST.2020.12.1.11

Amorim AG, Souza JM, Santos RC, Gullón B, Oliveira A, Santos LF, Virgino AL, Mafud AC, Petrilli HM, Mascarenhas YP (2018) HPLC-DAD, ESI-MS/MS, and NMR of lycopene isolated from P. Guajava L. and its biotechnological applications. Eur J Lipid Sci Technol 120:1700330. https://doi.org/10.1002/ejlt.201700330

Amorim AG, Souza J, Oliveira A, Santos RC, Vasconcelos AG, Souza L, Araújo T, Cabral W, Silva M, Mafud AC et al (2020) Anti-inflammatory and antioxidant activity improvement of lycopene from guava on nanoemulsifying system. J Dispers Sci Technol 42:760-770. https://doi.org/10.1080/01932691.2020.1728300

Amorim AGN, Leite JRSA, Ropke CD (2016) Obtenção de Extrato Rico Em Licopeno e Licopeno Puro de Fonte Natural. Patent BR102016030594-2

Baranowska-Wójcik E, Szwajgier D, Oleszczuk P, Winiarska-Mieczan A (2020) Effects of titanium dioxide nanoparticles exposure on human health—a review. Biol Trace Elem Res 193:1 18-129. https://doi.org/10.1007/ s12011-019-01706-6

Betageri GV (2019) Self-emulsifying drug delivery systems and their marketed products: a review. Asian J Pharm 13:73-84. https://doi.org/10.22377/ajp.v13i02.3102

Butelman ER, McElroy BD, Prisinzano TE, Kreek MJ (2019) Impact of pharmacological manipulation of the $k$-opioid receptor system on self-grooming and anhedonic-like behaviors in male mice. J Pharmacol Exp Ther 370:1-8. https://doi. org/10.1124/jpet.119.256354

Caetano-Silva ME, Simabuco FM, Bezerra RM, da Silva DC, Barbosa EA, Moreira DC, Brand GD, Leite JR, Pacheco MT (2020) Isolation and sequencing of $\mathrm{Cu}$-, Fe-, and $\mathrm{Zn}$-Binding whey peptides for potential neuroprotective applications as multitargeted compounds. J Agric Food Chem 68:12433-12443. https://doi.org/10.1021/acs.jafc.0c03647

Chernyshova MP, Pristenskiy DV, Lozbiakova MV, Chalyk NE, Bandaletova TY, Petyaev IM (2019) Systemic and skin-targeting beneficial effects of lycopene-enriched ice cream: a pilot study. J Dairy Sci 102:14-25. https://doi.org/10.3168/ jds.2018-15282

Cornbleet PJ (2002) Clinical utility of the band count. Clin Lab Med 22:101-136. https://doi.org/10.1016/S0272-2712(03) 00069-6

Crowley LC, Marfell BJ, Christensen ME, Waterhouse NJ (2016a) Measuring cell death by trypan blue uptake and light microscopy. Cold Spring Harb Protoc. https://doi.org/10.1101/pdb.prot087155

Crowley LC, Marfell BJ, Scott AP, Waterhouse NJ (2016b) Quantitation of apoptosis and necrosis by annexin v binding, propidium iodide uptake, and flow cytometry. Cold Spring Harb Protoc. https://doi.org/10.1101/pdb.prot087288

da Silva Brito AK, de Morais Lima G, de Farias LM, Rodrigues LARL, de Carvalho VBL, de Carvalho Pereira CF, de Macedo Gonçalves Frota K, Conde Júnior AM, Moura AMO, dos Santos Rizzo M et al (2019) Lycopene-rich extract from red guava (Psidium Guajava L.) decreases plasma triglycerides and improves oxidative stress biomarkers on experimentally-induced dyslipidemia in hamsters. Nutrients 11:393. https://doi.org/10.3390/nu11020393

D'Arcy MS (2019) Cell death: a review of the major forms of apoptosis, necrosis and autophagy. Cell Biol Int 43:582-592. https://doi.org/10.1002/cbin.11137 
dos Santos PP, Paese K, Guterres SS, Pohlmann AR, Costa TH, Jablonski A, Flôres SH, de Rios OA (2015) Development of lycopene-loaded lipid-core nanocapsules: physicochemical characterization and stability study. J Nanoparticle Res 17:107. https://doi.org/10.1007/s11051-015-2917-5

dos Santos RC, Ombredane AS, Souza JMT, Vasconcelos AG, Plácido A, das Amorim AGN, Barbosa EA, Lima FC, Ropke CD, Alves MM (2018) Lycopene-rich extract from red guava (Psidium Guajava L.) displays cytotoxic effect against human breast adenocarcinoma cell line MCF-7 via an apoptotic-like pathway. Food Res Int 105:184-196. https://doi.org/10. 1016/j.foodres.2017.10.045

Du B, Yu M, Zheng J (2018) Transport and Interactions of Nanoparticles in the Kidneys. Nat Rev Mater 3:358-374

EFSA (2015) Scientific Opinion on the Re-evaluation of Polyoxyethylene Sorbitan Monolaurate (E 432), Polyoxyethylene Sorbitan Monooleate (E 433), Polyoxyethylene Sorbitan Monopalmitate (E 434), Polyoxyethylene Sorbitan Monostearate (E 435) and Polyoxyethylene Sorbitan Tristearate (E 436) as Food Additives. EFSA J 13:4152, doi: https://doi. org/10.2903/j.efsa.2015.4152.

Ejike DE, Adam MA, Sheu OS, Nganda P, lliya E, Moses DA, Alfred OO (2018) Karimah lycopene attenuates diabetesinduced oxidative stress in wistar rats. J Diabetes Endocrinol 9:11-19. https://doi.org/10.5897/JDE2018.0118

Ferreira ALA, Yeum K-J, Liu C, Smith D, Krinsky NI, Wang X-D, Russell RM (2000) Tissue distribution of lycopene in ferrets and rats after lycopene supplementation. J Nutr 130:1256-1260. https://doi.org/10.1093/jn/130.5.1256

Friedrich RB, Kann B, Coradini K, Offerhaus HL, Beck RC, Windbergs M (2015) Skin penetration behavior of lipid-core nanocapsules for simultaneous delivery of resveratrol and curcumin. Eur J Pharm Sci 78:204-213

Ghelichpour M, Taheri Mirghaed A, Mirzargar SS, Joshaghani H, Ebrahimzadeh Mousavi H (2017) Plasma proteins, hepatic enzymes, thyroid hormones and liver histopathology of Cyprinus Carpio (Linnaeus, 1758) exposed to an oxadiazin pesticide Indoxacarb. Aquac Res 48:5666-5676. https://doi.org/10.1111/are.13390

Golla N, Hong LJ, Chefetz I (2021) Visualization of necroptotic cell death through transmission electron microscopy. In: Alvero AB, Mor GG (eds) Detection of cell death mechanisms. Methods in molecular biology, vol 2255. Springer, New York, pp 135-147

González-Reza RM, Quintanar-Guerrero D, Del Real-López A, Piñon-Segundo E, Zambrano-Zaragoza ML (2018) Effect of sucrose concentration and PH onto the physical stability of $\beta$-carotene nanocapsules. LWT 90:354-361. https://doi. org/10.1016/j.lwt.2017.12.044

Hedayati N, Naeini MB, Nezami A, Hosseinzadeh H, Wallace Hayes A, Hosseini S, Imenshahidi M, Karimi G (2019) Protective effect of lycopene against chemical and natural toxins: a review: lycopene against chemical and natural toxins. BioFactors 45:5-23. https://doi.org/10.1002/biof.1458

Kaga S, Truong NP, Esser L, Senyschyn D, Sanyal A, Sanyal R, Quinn JF, Davis TP, Kaminskas LM, Whittaker MR (2017) Influence of size and shape on the biodistribution of nanoparticles prepared by polymerization-induced self-assembly. Biomacromol 18:3963-3970. https://doi.org/10.1021/acs.biomac.7b00995

Korytko PJ, Rodvold KA, Crowell JA, Stacewicz-Sapuntzakis M, Diwadkar-Navsariwala V, Bowen PE, Schalch W, Levine BS (2003) Pharmacokinetics and tissue distribution of orally administered lycopene in male dogs. J Nutr 133:27882792. https://doi.org/10.1093/jn/133.9.2788

Kriegel C, Festag M, Kishore RSK, Roethlisberger D, Schmitt G (2019) Pediatric safety of polysorbates in drug formulations. Children 7:1-12. https://doi.org/10.3390/children7010001

Li D, Li L, Xiao N, Li M, Xie X (2018) Physical properties of oil-in-water nanoemulsions stabilized by OSA-modified starch for the encapsulation of lycopene. Colloids Surf Physicochem Eng Asp 552:59-66

Lindshield BL, King JL, Wyss A, Goralczyk R, Lu C-H, Ford NA, Erdman JW (2008) Lycopene biodistribution is altered in 15,15'-carotenoid monooxygenase knockout mice. J Nutr 138:2367-2371. https://doi.org/10.3945/jn.108.099663

Lu L-Q, Tian J, Luo X-J, Peng J (2021) Targeting the pathways of regulated necrosis: a potential strategy for alleviation of cardio-cerebrovascular injury. Cell Mol Life Sci 78:63-78. https://doi.org/10.1007/s00018-020-03587-8

Marsup P, Yeerong K, Neimkhum W, Sirithunyalug J, Anuchapreeda S, To-anun C, Chaiyana W (2020) Enhancement of chemical stability and dermal delivery of cordyceps militaris extracts by nanoemulsion. Nanomaterials 10:1565. https://doi.org/10.3390/nano10081565

Mirahmadi M, Azimi-Hashemi S, Saburi E, Kamali H, Pishbin M, Hadizadeh F (2020) Potential inhibitory effect of lycopene on prostate cancer. Biomed Pharmacother 129:110459. https://doi.org/10.1016/j.biopha.2020.110459

Nirmala JG, Lopus M (2020) Cell death mechanisms in eukaryotes. Cell Biol Toxicol 36:145-164. https://doi.org/10.1007/ s10565-019-09496-2

OECD (2002a) OECD Test No. 420: acute oral toxicity—fixed dose procedure; OECD Guidelines for the Testing of Chemicals, Section 4. ISBN 978-92-64-07094-3.

OECD (2002b) OECD guidance document on the recognition, assessment and use of clinical signs as human endpoints for experimental animals used in safety evaluation; OECD Series on Testing and Assessment. ISBN 978-92-64-07837-6.

OECD (2008) OECD Test No. 407: repeated dose 28-day oral toxicity study in rodents; OECD Guidelines for the Testing of Chemicals, Section 4. ISBN 978-92-64-07068-4.

Przybylska S (2020) Lycopene_-a bioactive carotenoid offering multiple health benefits: a review. Int J Food Sci Technol 55:11-32. https://doi.org/10.1111/ijfs.14260

Silva B, Marto J, Braz BS, Delgado E, Almeida AJ, Gonçalves L (2020) New nanoparticles for topical ocular delivery of erythropoietin. Int J Pharm 576:119020. https://doi.org/10.1016/j.jpharm.2020.119020

Singh S, Bajpai M, Mishra P (2020) Self-emulsifying drug delivery system (SEDDS): an emerging dosage form to improve the bioavailability of poorly absorbed drugs. Crit Rev Ther Drug Carr Syst 37:305-329. https://doi.org/10.1615/CritR evTherDrugCarrierSyst.2020033111

Smith MC, Crist RM, Clogston JD, McNeil SE (2017) Zeta potential: a case study of cationic, anionic, and neutral liposomes. Anal Bioanal Chem 409:5779-5787. https://doi.org/10.1007/s00216-017-0527-z

Srivastava S, Srivastava AK (2015) Lycopene; chemistry, biosynthesis, metabolism and degradation under various abiotic parameters. J Food Sci Technol 52:41-53. https://doi.org/10.1007/s13197-012-0918-2

Stice CP, Xia H, Wang X-D (2018) Tomato lycopene prevention of alcoholic fatty liver disease and hepatocellular carcinoma development. Chronic Dis Transl Med 4:211-224. https://doi.org/10.1016/j.cdtm.2018.11.001 
Stone KR, Mickey DD, Wunderli H, Mickey GH, Paulson DF (1978) Isolation of a human prostate carcinoma cell line (DU 145). Int J Cancer 21:274-281

Susilo RJK, Winarni D, Husen SA, Hayaza S, Punnapayak H, Wahyuningsih SPA, Sajidah ES, Darmanto W (2019) Hepatoprotective effect of crude polysaccharides extracted from ganoderma lucidum against carbon tetrachloride-induced liver injury in mice. Vet World 12:1987-1991. https://doi.org/10.14202/vetworld.2019.1987-1991

Tan B, Soderstrom DN (1989) Qualitative aspects of UV-Vis spectrophotometry of beta-carotene and lycopene. J Chem Educ 66:258. https://doi.org/10.1021/ed066p258

Tran P, Park JS (2021) Recent trends of self-emulsifying drug delivery system for enhancing the oral bioavailability of poorly water-soluble drugs. J Pharm Investig. https://doi.org/10.1007/s40005-021-00516-0

Vasconcelos AG, das Amorim GNA, dos Santos RC, Souza JM, de Souza LK, de Araújo SLT, Nicolau LA, de Lima-Carvalho L, de Aquino PE, da Silva-Martins C et al (2017) Lycopene rich extract from red guava (Psidium Guajava L.) displays anti-inflammatory and antioxidant profile by reducing suggestive hallmarks of acute inflammatory response in mice. Food Res Int 99:959-968. https://doi.org/10.1016/j.foodres.2017.01.017

Vasconcelos AG, Valim MO, Amorim AG, do Amaral CP, de Almeida MP, Borges TK, Socodato R, Portugal CC, Brand GD, Mattos JSC (2020) Cytotoxic activity of poly-e-caprolactone lipid-core nanocapsules loaded with lycopene-rich extract from red guava (Psidium Guajava L.) on breast cancer cells. Food Res Int 136:109548. https://doi.org/10. 1016/j.foodres.2020.109548

Wadie W, Mohamed AH, Masoud MA, Rizk HA, Sayed HM (2020) Protective impact of lycopene on ethinylestradiolinduced cholestasis in rats. Naunyn Schmiedebergs Arch Pharmacol 394:447-455. https://doi.org/10.1007/ s00210-020-01980-5

Wang XD (2012) Lycopene metabolism and its biological significance. Am J Clin Nutr 96:1214S-1222S. https://doi.org/10. 3945/ajen.111.032359

Wang C, Guan W, Chen R, Levi-Kalisman Y, Xu Y, Zhang L, Zhou M, Xu G, Dou H (2020) Fluorescent glycan nanoparticlebased FACS assays for the identification of genuine drug-resistant cancer cells with differentiation potential. Nano Res 13:3110-3122. https://doi.org/10.1007/s12274-020-2981-8

Wanyi W, Lu L, Zehan H, Xinan X (2020) Comparison of emulsifying characteristics of different macromolecule emulsifiers and their effects on the physical properties of lycopene nanoemulsions. J Dispers Sci Technol 41:618-627. https:// doi.org/10.1080/01932691.2019.1610421

Woźniak A, Malankowska A, Nowaczyk G, Grześkowiak BF, Tuśnio K, Słomski R, Zaleska-Medynska A, Jurga S (2017) Size and shape-dependent cytotoxicity profile of gold nanoparticles for biomedical applications. J Mater Sci Mater Med 28:92. https://doi.org/10.1007/s10856-017-5902-y

Wu X, Chen H, Wu C, Wang J, Zhang S, Gao J, Wang H, Sun T, Yang Y-G (2018) Inhibition of intrinsic coagulation improves safety and tumor-targeted drug delivery of cationic solid lipid nanoparticles. Biomaterials 156:77-87. https://doi. org/10.1016/j.biomaterials.2017.11.040

Xiong J, Xiong S, Guo Z, Yang M, Chen J, Fan H (2012) Ultrasonic dispersion of nano TiC powders aided by tween 80 addition. Ceram Int 38:1815-1821. https://doi.org/10.1016/j.ceramint.2011.10.004

Yen C-C, Chang C-W, Hsu M-C, Wu Y-T (1853) Self-nanoemulsifying drug delivery system for resveratrol: enhanced oral bioavailability and reduced physical fatigue in rats. Int J Mol Sci 2017:18. https://doi.org/10.3390/ijms18091853

Zardini AA, Mohebbi M, Farhoosh R, Bolurian S (2018) Production and characterization of nanostructured lipid carriers and solid lipid nanoparticles containing lycopene for food fortification. J Food Sci Technol 55:287-298

Zhao Z, Cui X, Ma X, Wang Z (2020) Preparation, characterization, and evaluation of antioxidant activity and bioavailability of a self-nanoemulsifying drug delivery system (SNEDDS) for buckwheat flavonoids. Acta Biochim Biophys Sin 52:1265-1274. https://doi.org/10.1093/abbs/gmaa124

Zhu Z, Wen Y, Yi J, Cao Y, Liu F, McClements DJ (2019) Comparison of natural and synthetic surfactants at forming and stabilizing nanoemulsions: tea saponin, quillaja saponin, and tween 80. J Colloid Interface Sci 536:80-87. https://doi. org/10.1016/j.jcis.2018.10.024

\section{Publisher's Note}

Springer Nature remains neutral with regard to jurisdictional claims in published maps and institutional affiliations.

Ready to submit your research? Choose BMC and benefit from:

- fast, convenient online submission

- thorough peer review by experienced researchers in your field

- rapid publication on acceptance

- support for research data, including large and complex data types

- gold Open Access which fosters wider collaboration and increased citations

- maximum visibility for your research: over 100M website views per year

At BMC, research is always in progress.

Learn more biomedcentral.com/submissions 